\title{
Genetic Variation for Nitrogen Efficiency in Oilseed Rape (Brassica napus L.)
}

\author{
Doctoral Dissertation \\ Submitted for the degree of Doctor of Agricultural Sciences \\ of the Faculty of Agricultural Sciences \\ Georg-August University of Göttingen
}

by

John Awan Nyikako

Born in Malakal, Sudan

Göttingen, July 2003 
D7

1. $1^{\text {st }}$ examiner: Prfo. Dr. H.C. Becker

2. $2^{\text {nd }}$ examiner: Prof. Dr. R. Rauber

Day of oral examination: 17.07.2003 


\section{Dedication}

Dedicated to all that are in search for a lasting peace, including members of my extended family and the entire people of Southern Sudan who are scattered abroad.

(John 14: 27) 


\section{Table of Contents}

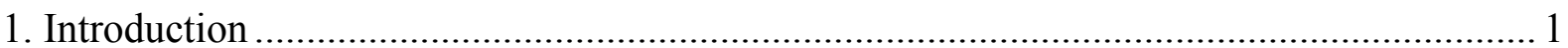

2. Genetic variation for $\mathrm{N}$ efficiency in $\mathrm{DH}$ lines of the cross 'Apex' $\mathrm{x}$ 'Mohican'.................. 6

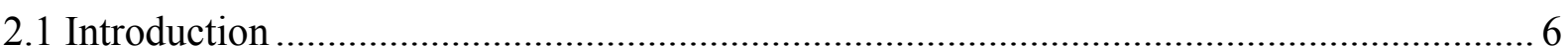

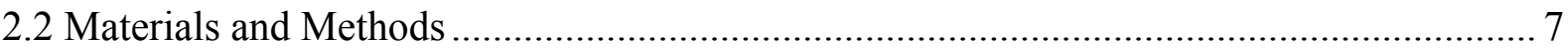

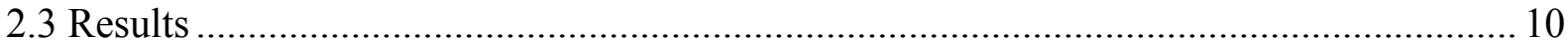

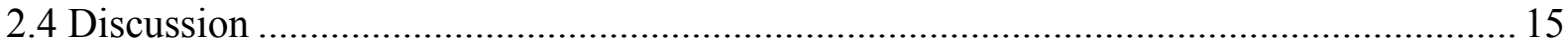

3. Genetic variation for $\mathrm{N}$ efficiency and correlations with other traits in the cross 'Mansholt $\mathrm{x}$

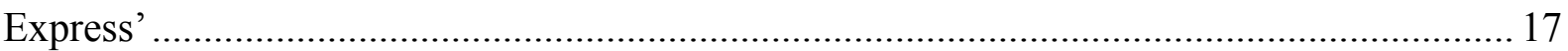

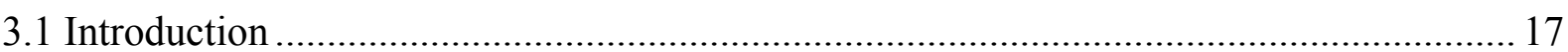

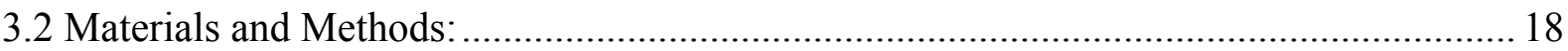

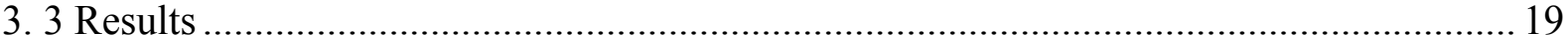

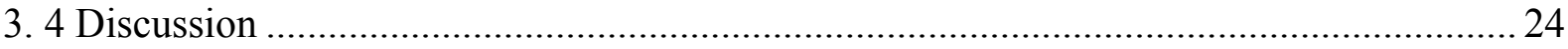

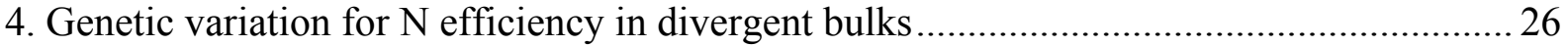

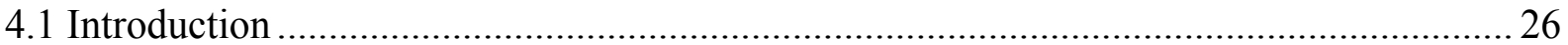

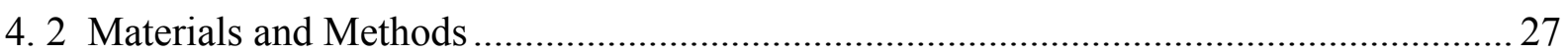

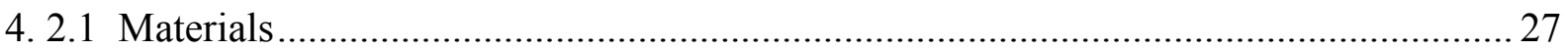

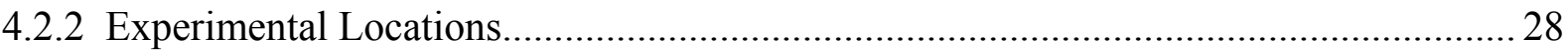

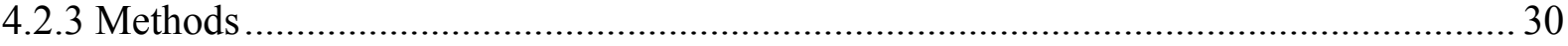

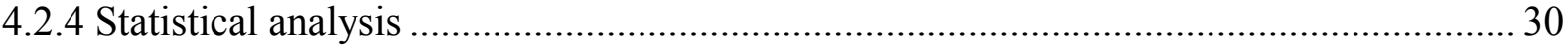

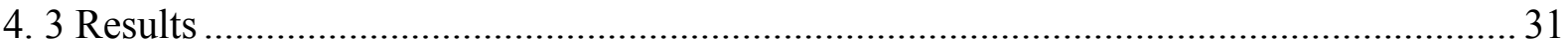

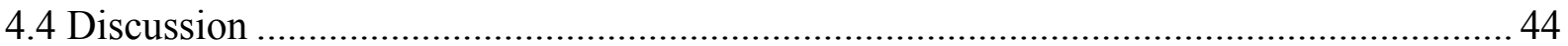

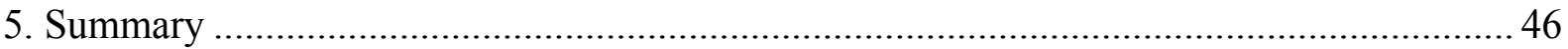

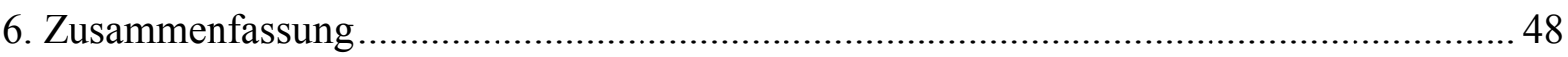

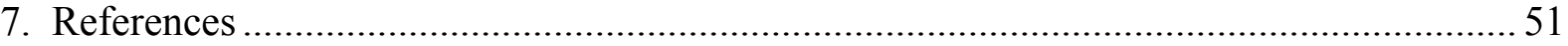

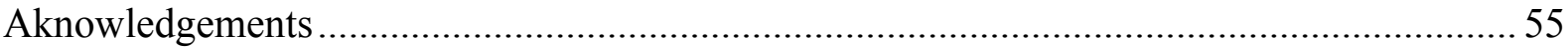

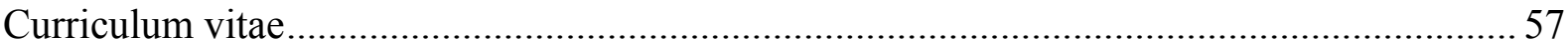




\section{Introduction}

Oilseed rape (Brassica napus L.) is one of the most important oilseed crops world wide with major production areas in Canada. China. European Union and India (Kimber and McGregor, 1995). The crop is grown mainly for oil for human nutrition (salad oil or margarine) as well as for industrial purposes (lubricants and hydraulic oils). The protein rich cake following oil extraction can be used for animal nutrition provided that breakdown products of glucosinolates are prevented by heat treatment (Schjoerring, 1995). The green revolution which was a major breakthrough in agricultural production to secure human nutrition ahead of population growth in the past century depends among other factors mainly on fertiliser application and breeding high yielding modern varieties. As a result modern cultivars grown today are selected for high input in order to obtain maximum grain yields. Also oilseed rape is produced today under high $\mathrm{N}$ fertiliser application making an unquestionable contribution to the increase of yield during the past century (Dreccer et al., 2000). However. the main problem of increased $\mathrm{N}$ supply is the decrease in $\mathrm{N}$ use efficiency. i.e. the greater the nitrogen application. the lower the additional $\mathrm{N}$ uptake by the crop. This is mainly due to the high $\mathrm{N}$ uptake until flowering. low $\mathrm{N}$ uptake during the reproductive growth phase and incomplete $\mathrm{N}$ translocation from vegetative plant parts to the seeds (Lickfett, 1993; Aniol, 1993). This results in a comparatively low nitrogen harvest index and a large surplus in $\mathrm{N}$ balance (Dreccer et al., 2000). The $\mathrm{N}$ surplus is at risk of leaving the plant-soil system either by leaching or by gaseous influx causing environmental hazards (Lickfett, 2000).

This has caused an recent interest in research to increase the efficient use of $\mathrm{N}$ fertiliser in different crops. Wiesler et al. (2001) have reported the combination of both reduced N supply and cultivation/breeding of $\mathrm{N}$ efficient cultivars as the means to reduce the $\mathrm{N}$ surpluses in oilseed rape. 
Much progress has been achieved in improving oilseed rape by breeding both in increasing grain yield as well as improving quality. the peak of which was the introduction of the double zero cultivars (low both in erucic acid and glucosinolates) and hence a wide range of cultivars are now in cultivation. However. successful breeding of $\mathrm{N}$ efficient oilseed rape depends beside other factors on the existence of genetic variation for the trait in question.

Genotypic variation in nutrient efficiency is complicated in the first place by the absence of a generally accepted definition of $\mathrm{N}$ efficiency. A genotype can be termed $\mathrm{N}$ efficient either when realising a high yield under conditions of low N supply (Graham, 1984) or when converting $\mathrm{N}$ fertiliser efficiently into yield under conditions of high $\mathrm{N}$ supply (Sattelmacher et al.., 1994).

$\mathrm{N}$ efficiency can be splitted into two components (Moll et al., 1982) i.e. $\mathrm{N}$ uptake ( the efficiency with which the soil $\mathrm{N}$ can be taken up by the plant) and $\mathrm{N}$ utilisation efficiency (the seed dry weight per unit of absorbed $\mathrm{N}$ fertiliser). Genotypic variation in $\mathrm{N}$ efficiency could generally be attributed to high $\mathrm{N}$ uptake and/or high $\mathrm{N}$ utilisation (Sattelmacher et al., 1994). To develop a breeding programme which could successfully improve $\mathrm{N}$ efficiency it is therefore necessary to clearly define the breeding objectives: what is defined as a $\mathrm{N}$ efficient cultivar and who is the end user for whose benefit the breeding is carried out; is he a developed farmer who seeks more efficient use of fertiliser. greater economy and less pollution of ground water? Or a farmer in the developing world whose interest is producing reasonable yield with minimum fertiliser input (Vose, 1990).

Effective selection with the goal of improving $\mathrm{N}$ efficiency necessitates testing at different $\mathrm{N}$ levels. Testing only under optimal conditions of oil seed production could lead to masking of the differences among the genotypes in components of $\mathrm{N}$ efficiency. as reported with different crops (Muruli and Paulsen, 1981; Rauna and Johnson, 1999; Möllers, 2000; Gueye, 2002).

Genetic variation in the $\mathrm{N}$ uptake and $\mathrm{N}$ utilisation has been demonstrated with many field crops. Spanakakis (2000) working with wheat has shown the feasibility of selecting high 
yielding cultivars with better quality. Presterl et al. (2000) successfully selected N efficient genotypes when screening under low and high $\mathrm{N}$ supply in studying the $\mathrm{N}$ efficiency in maize. Maidl et al. (2000) studying $\mathrm{N}$ efficiency in 40 cultivars of barley under $3 \mathrm{~N}$ levels found significant genotypic differences for $\mathrm{N}$ uptake and $\mathrm{N}$ utilisation in the sub-optimal $\mathrm{N}$ supply. Investigation of $\mathrm{N}$ efficiency in oilseed rape with field experiments were started with spring rape in Canada (Grami and La Croix, 1977) followed by Yau and Thurling (1987a) in Australia who worked with spring oilseed rape with field experiments in $3 \mathrm{~N}$ levels. Their results demonstrated the existence of genotypic variation for $\mathrm{N}$ utilisation under sub-optimal $\mathrm{N}$ supply and for $\mathrm{N}$ uptake in the intermediate $\mathrm{N}$ supply. Yau and Thurling (1987b) were able to detect genetic variation for both $\mathrm{N}$ uptake and utilisation efficiencies in a segregating population. Multi-locational field trials with modern cultivars of winter oilseed rape were carried out by Möllers et al. (2000) in two N levels. observing significant interactions between genotype and $\mathrm{N}$ level. suggesting that the high yielding genotypes in high $\mathrm{N}$ supply were not necessarily high yielding in the low N supply. Kessel and Becker (1999a) investigating 70 genotypes including lines. hybrids. resynthesized oilseed rape lines and crosses with resyntheses in two $\mathrm{N}$ levels have shown. that the resyntheses were always low yielding with a very high correlation between the $\mathrm{N}$ levels. while this correlation is low for the other groups. The $\mathrm{N}$ yield of the straw showed a genetic variation only at the reduced $\mathrm{N}$ supply. The genetic variation was significant for both $\mathrm{N}$ yield of seed and straw at both $\mathrm{N}$ levels. $\mathrm{N}$ yields for seed and straw were not correlated. The same authors also investigated genetic variation for both uptake and utilisation efficiency in 90 genotypes from different groups (lines. hybrids. old land varieties. resyntheses and crosses between Falcon and resyntheses). Resyntheses were found to be the group with lowest grain yield and lowest $\mathrm{N}$ harvest index. $\mathrm{N}$ content of the dropped leaves showed significant reaction to nitrogen supply and a large genetic variation at both $\mathrm{N}$ levels (Kessel and Becker, 1999b). 
In order to use the genetic variation in $\mathrm{N}$ uptake and $\mathrm{N}$ utilisation as selection criteria in improving oilseed rape breeding it is necessary to measure the response to $\mathrm{N}$ supply on traits related to the components of $\mathrm{N}$ efficiency. We have measured a range of agronomic traits apart from grain yield which might be related to $\mathrm{N}$ efficiency and which could eventually serve as traits of indirect selection in improving $\mathrm{N}$ efficiency in oilseed rape.

The present work is a further contribution in the effort to better understand the genetic variation of oilseed rape for $\mathrm{N}$ efficiency and hence increase $\mathrm{N}$ use efficiency.

Production of a new cultivar takes usually more than a decade and it involves also huge funds. the success of a breeding programme therefore will require effectiveness in the different steps of breeding (Becker et. al., 1999). this necessites the search for quick. cheap and accurate methods of measurement (Buzza, 1995). Breeding therefore for agronomic traits related to $\mathrm{N}$ efficiency could serve as means of indirect selection criteria to improve $\mathrm{N}$ efficiency in oilseed rape. Since $\mathrm{N}$ use efficiency is represented by both $\mathrm{N}$ uptake and $\mathrm{N}$ utilisation. agronomic traits to be measured should be related to either of the two components.

Field trials were conducted in different locations over two years with two $\mathrm{N}$ levels (without fertiliser and with high $\mathrm{N}$ fertilisation). The material consisted of three populations of double haploid lines (DH-Lines) derived from the crosses between the varieties 'Apex' and 'Mohican' . 'Express'and 'Mansholt'. 'Bristol' and 'Lirajet'. Divergent bulks were produced out of the above populations according to traits assumed to be related to $\mathrm{N}$ use efficiency. the bulks are different in many other traits but similar in the selected traits to be compared. The use of bulks has also the advantage of reducing the number of lines to be tested. because only pairs of two divergent bulks each are compared with one another.

This work consisted of three different experiments which will be presented in three separate chapters. 
1. Genetic variability for $\mathrm{N}$ efficiency in a $\mathrm{DH}$ line population derived from a cross of the cultivars 'Apex' and 'Mohican'. The main objective in this part is to investigate the relative importance of the components uptake and utilisation efficiency.

2. Genetic variability for $\mathrm{N}$ efficiency in a $\mathrm{DH}$ line population derived from a cross of the cultivars 'Express' and 'Mansholt'. In this population correlations between agronomic and other traits are analysed at two $\mathrm{N}$ levels.

3. Genetic variability for $\mathrm{N}$ efficiency in divergent bulks derived from the cross of the above two populations and a cross of the cultivars 'Bristol' and 'Lirajet'. The divergent bulks are used to identify relationships between $\mathrm{N}$ efficiency and agronomic traits. 


\section{Genetic Variation for $\mathbf{N}$ efficiency in DH lines of the cross 'Apex' $x$ 'Mohican'}

\subsection{Introduction}

The principal objective of breeding oilseed rape has been an increasing grain yield per unit land surface (Becker et. al., 1999) and since selection for new cultivars has been carried out under conditions of optimal $\mathrm{N}$ supply the modern cultivars are adapted to such production conditions.

Oilseed rape is known to be having a low $\mathrm{N}$ harvest index which is due to the incomplete retranslocation of $\mathrm{N}$ from the vegetative organs into the seed in reproductive growth stages despite the high $\mathrm{N}$ uptake early in the season. which results in leaching of a larger portion of the absorbed $\mathrm{N}$ in the straw to the ground water as nitrate (Lickfett et al., 1993) contributing therefore to environmental pollution.

The growing awareness concerning environmental pollution in Europe and Germany demands reconsideration of breeding objectives to include screening of the existing genetic materials in order to select for $\mathrm{N}$ efficient cultivars (Möllers et. al., 2000).

To investigate genetic variation for $\mathrm{N}$ efficiency the selection environment is very important. It is well documented in the literature that selection for $\mathrm{N}$ efficiency under different $\mathrm{N}$ supply leads to different results due to GxN interaction (Muruli and Paulsen, 1981; Möllers, 2000). Hence it is important to investigate the genetic variation under both optimal and sub-optimal $\mathrm{N}$ supply. the obtained $(\mathrm{GxN})$ interaction here will lead to the identification of cultivars for both high and low input agricultural production (Becker, 1993).

$\mathrm{N}$ efficiency can be splitted into two components (Moll et al., 1982) i.e. $\mathrm{N}$ uptake ( the efficiency with which the soil $\mathrm{N}$ can be taken up by the plant) and $\mathrm{N}$ utilisation efficiency (the seed dry weight pro unit of absorbed $\mathrm{N}$ fertiliser). Genotypic variation in $\mathrm{N}$ efficiency could generally be attributed to high $\mathrm{N}$ uptake and/or high $\mathrm{N}$ utilisation (Sattelmacher et al., 1994). 
In order to increase breeding efficiency agronomic traits related to $\mathrm{N}$ uptake and $\mathrm{N}$ utilisation could serve as means of indirect selection criteria to improve $\mathrm{N}$ efficiency in oilseed rape.

The use of DH lines in indirect selection is promising where grain yield is to be correlated with agronomic traits, as genetically homogeneous populations they produce better results in biomass harvesting compared to conventional cultivars (Kessel, 2000). Time saving in breeding is a most obvious advantage of $\mathrm{DH}$ lines since yield and other traits could be tested much earlier than with conventional cultivars (Kucera et. al., 2002).

The aim of this study was to investigate genetic variation for $\mathrm{N}$ use efficiency and its components in a $\mathrm{DH}$ population derived from the cross of two modern high yielding cultivars.

\subsection{Materials and Methods}

Fifty four doubled haploid lines derived from a cross between the two varieties 'Apex' and 'Mohican' and the parents were evaluated in field experiments in seven environments in northern Germany.

The environments were: Göttingen-Reinshof in three years (1999/2000/2001), GöttingenKlärwerk in 1999 and Göttingen-Dragoneranger in 2001 (experimental stations of the University of Göttingen), and Teendorf in the growing seasons 1999 and 2001 (experimental station of the breeding company Semundo).

The treatments were arranged in 8x7 lattice design except for Göttingen-Klärwerk, 1999, Göttingen-Reinshof. 2000, and Göttingen-Dragoneranger 2001 where Randomised Complete Block Design (RCB) was used. All the experiments were in two replications and two nitrogen (N) levels. The $\mathrm{N}$ levels were: unfertilised (N0) and $240 \mathrm{~kg} \mathrm{~N} /$ ha (including $\mathrm{N}_{\min }$ measured in early spring). The fertiliser was applied in two doses: the first portion at the beginning of vegetation early in the year and the second portion four weeks later. Plot size was $11.25 \mathrm{~m}^{2}$ in Göttingen and $15 \mathrm{~m}^{2}$ in Teendorf. 
The agronomic traits measured in the field in Göttingen were days to begin of flowering (days after $1^{\text {st }}$ April where about $10 \%$ of the plants in the plots started to flower). end of flowering (days where only $10 \%$ of flowers were still seen on the lower branches in a plot). flowering interval (difference between end and begin of flowering. in days). Chlorophyll content. measured in the upper most leaves of ten plants/plot with the chlorophyll meter Spad-502 (Minolta) and plant height at both begin and end of flowering (the height in $\mathrm{cm}$ from soil surface to the plant tip). At Teendorf. only days to begin of flowering. plant height at end of flowering and grain yield were measured.

Plants were sampled for above ground biomass and $\mathrm{N}$ content at both begin and end of flowering (Göttingen-Reinshof 1999/2000/2001) and Göttingen-Dragoneranger 2001). at each harvest plants within $1 \mathrm{~m}^{2}$ each plot (excluding border rows) were cut off at ground level. and after determining the total fresh weight. representative samples were dried to calculate dry weight. Freshly dropped leaves were also sampled by collecting the freshly shed leaves in the middle of a plot. All the samples were then dried at $60{ }^{\circ} \mathrm{C}$ for several days then milled passing through a $0.5 \mathrm{~mm}$ screen for the determination of $\mathrm{N}$ concentration using NIRS (Near-Infrared-Reflectance-Spectroscopy). (Velasco and Möllers 2000).

The rest of the plots were harvested at maturity. the total straw weight was determined (four environments in Göttingen) from which a sample was taken for drying. grinding and determination of $\mathrm{N}$ content. Thousand seed weight was determined in all the environments. Oil and protein contents were measured by NIRS. (Reinhardt 1992).

Moll et al.. (1982 expressed N use efficiency and its components as follows:

$\mathrm{N}$ use efficiency $=\mathrm{Gw} / \mathrm{Ns}$

Uptake efficiency $=\mathrm{Nt} / \mathrm{Ns}$

Utilisation efficiency $=\mathrm{Gw} / \mathrm{Nt}$

Nitrogen efficiency $=$ Uptake efficiency $\mathrm{x}$ Utilisation efficiency

Where: 
$\mathrm{Gw}=$ grain yield $(\mathrm{kg} / \mathrm{ha}) . \mathrm{Ns}=\mathrm{N}$ supply $(\mathrm{kg} / \mathrm{ha}) . \mathrm{Nt}=\mathrm{N}$ content in the plant $(\mathrm{kg} / \mathrm{ha})$.

Partitioning of the variation for $\mathrm{N}$ efficiency into uptake and utilisation efficiencies under the low and high $\mathrm{N}$ levels were also calculated according to Moll et al. (1982). The original values are logarithmically transformed to allow a partitioning into additive components in an analysis of variance as follows:

$\mathrm{N}$ efficiency $\mathrm{Y}=\log (\mathrm{Gw} / \mathrm{Ns})$

Uptake efficiency $\mathrm{X} 1=\log (\mathrm{Nt} / \mathrm{Ns})$

Utilisation efficiency $\mathrm{X} 2=\log (\mathrm{Gw} / \mathrm{Nt})$

Variance of N efficiency VAR (Y) = Covariance $(\mathrm{YX} 1)+$ Covariance $(\mathrm{YX} 2)$

Uptake efficiency A = Covariance (YX1)/VAR (Y)

Utilisation efficiency $\mathrm{U}=$ Covariance $(\mathrm{YX} 2) / \mathrm{VAR}(\mathrm{Y})$

The $\mathrm{N}$ efficiency and its components were calculated separately for $\mathrm{N} 0$ and $\mathrm{N} 240 \mathrm{~kg} \mathrm{~N} / \mathrm{ha}$. from the yield and total $\mathrm{N}$ content in the plant. $\mathrm{N}$ supply (Ns) was estimated from the cultivar with maximum total $\mathrm{N}$ uptake $+\mathrm{N}_{\text {min }}$ following harvest in each $\mathrm{N}$ level. it was considered to be the same for all the genotypes in each $\mathrm{N}$ level.

Collected data from the field were used to calculate the following secondary traits:

Protein $=\mathrm{N}$ seed content $\times 6.25$

$\mathrm{N}$ seed uptake $=\mathrm{Gw} \times \mathrm{N}$ seed

$\mathrm{N}$ uptake $_{\mathrm{EF}}=\mathrm{DwS}_{\mathrm{EF}} \mathrm{x} \mathrm{N}$ stover $_{\mathrm{EF}}$

$\mathrm{N}$ uptake straw $=$ DwSt $\times \mathrm{N}$ straw

Plant total $\mathrm{N}$ uptake $=($ DwSt $\times \mathrm{N}$ straw $+\mathrm{Gw} \times \mathrm{N}$ seed $)$

Harvest index $=\mathrm{GW} /(\mathrm{DwSt}+\mathrm{Gw})$

$\mathrm{N}$ harvest index $=\mathrm{N}$ uptake seed $/$ Plant total $\mathrm{N}$ uptake

Where:

$\mathrm{Gw}=$ seed yield $(\mathrm{dt} / \mathrm{ha})$

$\mathrm{DwS}_{\mathrm{EF}}=$ stover dry weight at end of flowering. DwSt $=$ straw dry weight at maturity 
Analysis of variance was computed using PLABSTAT (Plant Breeding Statistical Programme, UTZ, 1997). N levels were considered fix whereas environments. replications and lines were assumed random.

\subsection{Results}

The analysis of variance (ANOVA) for grain yield shows highly significant differences between the tested genotypes as well as a $(\mathrm{GxN})$ interaction. the variance components of $\mathrm{GN}$ and GE were about half as large as the genotypic variance (Table.1).

Table 1: Analysis of variance for grain yield (dt/ha). seven Environments.

\begin{tabular}{l|llll}
\hline Source of variation & $D F$ & $M S$ & Var.comp & F-value \\
\hline Environment (E) & 6 & 2211.88 & 19.61 & $137.60 * *$ \\
Nitrogen (N) & 1 & 82069.60 & 206.26 & $66.93 * \star$ \\
Genotypes (G) & 55 & 86.37 & 5.02 & $5.37 * *$ \\
NE & 6 & 1201.45 & 21.26 & $110.65 * *$ \\
GE & 321 & 16.07 & 2.61 & $1.48 * *$ \\
GN & 55 & 24.93 & 2.01 & $2.30 * *$ \\
GNE & 321 & 10.86 & 10.86 & \\
\hline
\end{tabular}

*. ** Significant at $\mathrm{P}=0.05 . \mathrm{P}=0.01$. respectively 


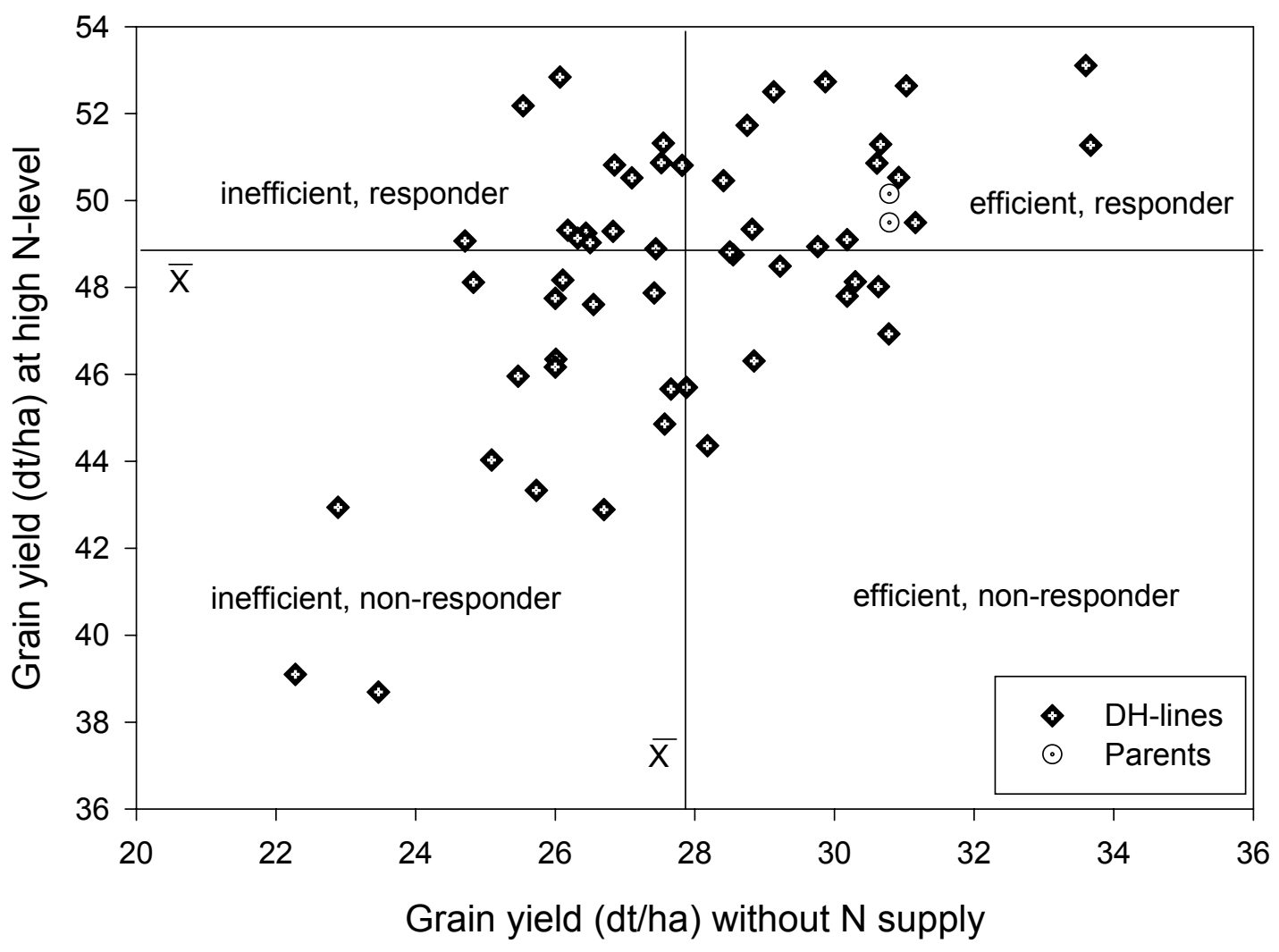

Fig. 1: Distribution of the DH-lines according to grain yields (dt/ha). seven environments.

Distribution of the DH-lines according to grain yield with and without fertiliser application is shown in Figure 1. There is large segregation of the DH-lines in their reaction to N supply. though the parents were not different in their yield potentials in the two N-levels. The DHlines segregated into in-efficient/non-responder (always low yielding in the two $\mathrm{N}$ levels). efficient/responder (high yielding in sub-optimal $\mathrm{N}$ supply but respond with increased yield to additional $\mathrm{N}$ supply). in-efficient/responder (high yielding only in response to added fertiliser) and efficient non-responder (high yielding in sub-optimal $\mathrm{N}$ supply only). Most of the lines were efficient/responders and inefficient/non-responders (responders were the lines capable of 
producing average grain yield with the additionally supplied N. non-responders are those which fail to translate the additionally supplied $\mathrm{N}$ to grain yield).

Table 2: Analysis of variance for total plant $\mathrm{N}$ uptake and $\mathrm{N}$ utilisation ( $\mathrm{Kg} \mathrm{N} / \mathrm{ha}$ ). four environments.

\begin{tabular}{|c|c|c|c|c|c|}
\hline \multirow{2}{*}{ Source of variation } & \multirow{2}{*}{$D F$} & \multicolumn{2}{|l|}{ Uptake } & \multicolumn{2}{|c|}{ Utilisation } \\
\hline & & $M S$ & Var.cp & $M S$ & Var.cp \\
\hline Environment (E) & 3 & 21321.16 & $188.27 * *$ & 35.41 & $0.27 * *$ \\
\hline Nitrogen $(\mathrm{N})$ & 1 & 1781059.76 & $7898.51 * *$ & 6273.56 & $27.90 * *$ \\
\hline Genotypes (G) & 55 & 458.92 & $27.93 * *$ & 18.80 & $1.67 * *$ \\
\hline NE & 3 & 11699.14 & $205.29 * *$ & 22.91 & $0.32 * *$ \\
\hline GE & 156 & 235.49 & 16.22 & 5.51 & 0.26 \\
\hline GN & 55 & 298.25 & $23.80^{*}$ & 6.71 & $0.43+$ \\
\hline GNE & 156 & 203.05 & 203.05 & 5.00 & 5.00 \\
\hline
\end{tabular}

The ANOVA (Table 2) shows a highly significant genotypic variability for both total plant $\mathrm{N}$ uptake and $\mathrm{N}$ utilisation. Total plant $\mathrm{N}$ uptake has shown a significant $(\mathrm{GxN})$ interaction. whereas this interaction was only significant at $\mathrm{P}=10 \%$ for the $\mathrm{N}$ utilisation. The environmental influence was highly significant for the above traits.

Splitting the $\mathrm{N}$ efficiency into its components shows that the genotypic variability for $\mathrm{N}$ efficiency was mainly caused by differences in uptake efficiency in N0 and by differences in utilisation efficiency under conditions of high $\mathrm{N}$ supply at the two sites in the growing season 2001 (Table 3). There was a lower variation in $\mathrm{N}$ utilisation at high $\mathrm{N}$ supply in 1999 and 2000. whereby $\mathrm{N}$ uptake determined the $\mathrm{N}$ efficiency irrespectively of $\mathrm{N}-$ level. However. the above trend was confirmed. considering the average of four environments. with a larger contribution of uptake efficiency (0.62) in the N0 and of utilisation efficiency (0.64) in N240. 
Table 3: Partitioning variation in $\mathrm{N}$ efficiency into contributions of uptake and utilisation efficiency

\begin{tabular}{l|crrr}
\hline \multirow{2}{*}{ Environments } & \multicolumn{3}{|c}{$N 0$} & \multicolumn{3}{c}{$N 240$} \\
\cline { 2 - 5 } & $\begin{array}{r}N \text {-Uptake } \\
(N t / N s)\end{array}$ & $\begin{array}{r}\text { N-Utilisation } \\
(G w / N t)\end{array}$ & $\begin{array}{c}N \text {-Uptake } \\
(N t / N s)\end{array}$ & $\begin{array}{c}N \text {-Utilisation } \\
(G w / N t)\end{array}$ \\
\hline Reinshof 2001 & 0.56 & 0.44 & 0.32 & 0.68 \\
Dragoneranger 2001 & 0.81 & 0.19 & 0.19 & 0.69 \\
Reinshof 2000 & 0.66 & 0.34 & 0.59 & 0.41 \\
Reinshof 1999 & 0.68 & 0.32 & 0.62 & 0.38 \\
Mean of four & 0.62 & 0.38 & 0.36 & 0.64 \\
Environments & & & & \\
\hline
\end{tabular}

Considering the correlation of $\mathrm{N}$ efficiency with other agronomic traits (Table 4). grain yield shows high significant correlation with both $\mathrm{N}$ uptake and utilisation efficiencies at the limiting $\mathrm{N}$ supply $\left(\mathrm{r}=0.72^{* *}\right.$ and $0.56^{* *}$. respectively) indicating the importance of these components in yield formation. Oil content was highly correlated with $\mathrm{N}$ efficiency at both $\mathrm{N}$ levels $\left(\mathrm{r}=0.41^{* *}\right.$ and $\mathrm{r}=0.71^{* *}$ at $\mathrm{N} 0$ and N240. respectively). The protein content on the other hand was negatively correlated with $\mathrm{N}$ efficiency irrespective of the $\mathrm{N}$ fertilisation.

$\mathrm{N}$ efficiency was correlated with $\mathrm{HI}$ in the two $\mathrm{N}$ levels. nevertheless utilisation efficiency was the highest correlated component of $\mathrm{N}$ efficiency with $\mathrm{HI}$ under conditions of $\mathrm{N}$ deficiency in the soil $\left(\mathrm{r}=0.46^{* *}\right)$. Easily measured traits such as thousand seed weight. plant height and flowering dates have shown correlations to $\mathrm{N}$ efficiency or its components only at the high $\mathrm{N}$ level. where large seeds. short plants and early flowering is correlated with high $\mathrm{N}$ utilisation efficiency. 
Table 4: Correlation of N-Efficiency components with morphological traits (4 environments)

\begin{tabular}{|c|c|c|c|c|c|c|}
\hline \multirow{3}{*}{$\begin{array}{l}\text { Traits } \\
\text { TSW (g) }\end{array}$} & \multicolumn{2}{|c|}{$N$-Eficiency $(G W / N S)$} & \multicolumn{2}{|c|}{$N$-Uptake $(N t / N s)$} & \multicolumn{2}{|c|}{$N$-Utilisation $(\mathrm{Gw} / \mathrm{Nt})$} \\
\hline & NO & $N 240$ & NO & 40 & $N 24$ & \\
\hline & -0.24 & 0.02 & -0.08 & 0.15 & -0.24 & $0.83 * *$ \\
\hline BF (days) & 0.10 & $-0.28 *$ & 0.04 & -0.10 & 0.10 & $-0.77 * *$ \\
\hline EF (days) & -0.08 & $-0.47 * *$ & 0.05 & -0.08 & -0.16 & $-0.53 * *$ \\
\hline FI (days) & -023 & -0.10 & 0.02 & 0.06 & $-0.36 * *$ & $0.58 * *$ \\
\hline $\mathrm{P} 1$ height $_{\mathrm{BF}}(\mathrm{cm})$ & -0.11 & 0.14 & -0.13 & 0.25 & 0.01 & -0.21 \\
\hline $\mathrm{Pl}$ height $_{\mathrm{EF}}(\mathrm{cm})$ & 0.06 & -0.02 & 0.01 & $0.27 *$ & 0.08 & $-0.41 * *$ \\
\hline Chlorophyll & 0.05 & -0.17 & 0.03 & -0.06 & 0.02 & -0.14 \\
\hline $\mathrm{N}$ uptake $_{\mathrm{EF}}(\mathrm{kgN} / \mathrm{ha})$ & $0.31 *$ & 0.17 & $0.37 * *$ & $0.27 *$ & 0.00 & -0.07 \\
\hline DwSt (dt/ha) & $0.38 * *$ & 0.03 & $0.54 * *$ & $0.72 * *$ & -0.09 & -0.11 \\
\hline N uptake Strew (kgN/ha) & 0.21 & 0.01 & $0.55^{* *}$ & $0.76^{* *}$ & $-0.35 * *$ & -0.03 \\
\hline Yield (dt/ha) & $1.00 * *$ & * 1.00 & $0.72 * *$ & $0.40 * *$ & $0.56^{* *}$ & 0.18 \\
\hline Oil (\%) & $0.41 * *$ & $0.71 * *$ & 0.24 & 0.13 & $0.30^{*}$ & -0.02 \\
\hline Protein $(\%)$ & $-0.51 * *$ & $-0.74 * *$ & -0.19 & 0.08 & $-0.50 * *$ & 0.04 \\
\hline Seed N uptake $(\mathrm{kgN} / \mathrm{ha})$ & $0.76^{* *}$ & $0.61 * *$ & $0.76^{* *}$ & $0.77 * *$ & 0.17 & $0.31 *$ \\
\hline Total plant $\mathrm{N}$ uptake (kgN/ha) & $0.72 * *$ & $0.40 * *$ & $1.00 * *$ & $1.00 * *$ & -0.78 & 0.17 \\
\hline Total plant dry weight (dt/ha) & $0.68 * *$ & $0.32 *$ & $0.69 * *$ & $0.80 * *$ & 0.14 & -0.06 \\
\hline Ndropped leaves(\%) & $0.39 * *$ & -0.18 & $0.32 *$ & -0.14 & 0.17 & 0.03 \\
\hline HI & $0.45 * *$ & $0.36^{* *}$ & 0.13 & $-0.51 * *$ & $0.46^{* *}$ & 0.14 \\
\hline NHI & 0.04 & 0.17 & -0.17 & $-0.56 * *$ & $0.40 * *$ & 0.06 \\
\hline
\end{tabular}

TSW $=$ Thousand seed weight. BF $=$ Beginning of flowering. EF $=$ End of flowering. FI $=$ Flowering interval. $\mathrm{SNU}=$ Seed $\mathrm{N}$ uptake. $\mathrm{NDL}=\mathrm{N}$ in dropped leaves 


\subsection{Discussion}

This study was performed to investigate the magnitude of genetic variation for $\mathrm{N}$ use efficiency as well as its correlation with agronomic traits to find strategies for an indirect selection.

\section{Nitrogen uptake and utilisation efficiencies}

The $\mathrm{N}$ use efficiency was defined as the grain produced per unit of available soil $\mathrm{N}$ supply and it was partitioned into two components. namely $\mathrm{N}$ uptake (the efficiency with which $\mathrm{N}$ is taken up from the soil) and $\mathrm{N}$ utilisation (the efficiency with which the absorbed $\mathrm{N}$ is converted into yield) according to Moll et al. (1982).

Our results have shown that genetic variation for $\mathrm{N}$ use efficiency depended significantly on the level of $\mathrm{N}$ fertilisation as a result differences in the $\mathrm{N}$ use efficiency and its components were observed at the two $\mathrm{N}$ levels. (Table 5) presents similar results from different experiments for comparison. Maidel et al. (2000) found no relationship between the N supply and the components of $\mathrm{N}$ use efficiency. Our results have clearly demonstrated that the genetic variation for $\mathrm{N}$ uptake is of more importance for $\mathrm{N}$ efficiency under conditions of suboptimal $\mathrm{N}$ supply. whereas $\mathrm{N}$ utilisation shown to be decessive under high $\mathrm{N}$ supply. These

results were in agreement with the earlier work of Kessel. 2000 with oilseed rape. OrtizMonsaterio et. al. (1997) with wheat and Becker and Kazman (2000) with triticale. 
Table 5: Relative contribution of $\mathrm{N}$ uptake and $\mathrm{N}$ utilisation (\%)

\begin{tabular}{|c|c|c|c|c|c|}
\hline \multirow[t]{2}{*}{ Crop } & \multicolumn{2}{|c|}{ Low N supply } & \multicolumn{2}{|c|}{ High N supply } & \multirow[t]{2}{*}{ Source } \\
\hline & $N$-Uptake & $N$-Utilisation & $N$-Uptake & $N$-Utilisation & \\
\hline Wheat & - & - & 54 & 46 & $\begin{array}{ll}\text { Van Sanford } & \& \\
\text { Mackow } 1986 & \end{array}$ \\
\hline Wheat & 62 & 38 & 70 & 30 & $\begin{array}{l}\text { Dhugga \& Waines } \\
1989\end{array}$ \\
\hline Wheat & 86 & 14 & 30 & 70 & $\begin{array}{l}\text { Ortiz-Monasterio et } \\
\text { al.. } 1997\end{array}$ \\
\hline Barley & 71 & 29 & 67 & 33 & Maidel et al.. 2000 \\
\hline Oilseed rape & 58 & 42 & 27 & 73 & Kessel 2000 \\
\hline Oilseed rape & 62 & 38 & 36 & 64 & Nyikako 2003 \\
\hline
\end{tabular}

Modified after Becker and Kazman. 2002

It is to be mentioned that the materials listed in the above table consisted of genetically more or less selected material and the results may be influenced by the structure of the material. In the present investigation unselected lines from one DH population were used. This has the advantage that correlations and variances observed are independent of arbitrary effects when selecting the material.

\section{Advantages of using DH lines}

Figure1 clearly show the large segregation of the DH lines in their yield potentials despite the only slide difference between the standard cultivars 'Apex' $x$ 'Mohican' from which they were derived. This fact has really demonstrated the possibility of selecting progeny exceeding the performance of the parents using DH lines technique.

In conclusion these results have shown the feasibilty of breeding for $\mathrm{N}$ efficient oilseed rape due to the significant GxN interaction for grain yield as well as for components of $\mathrm{N}$ efficiency and that testing the genotypes under two $\mathrm{N}$ levels ( high and low $\mathrm{N}$ supply) is enough in order to detect genotypic variations. 


\section{Genetic variation for $\mathbf{N}$ efficiency and correlations with other traits in the cross} 'Mansholt x Express'

\subsection{Introduction}

The main aim of plant breeding generally is to produce a cultivar by improving one trait or more. however. the chances of success in the first place depends on the genetic variation for the trait in question. after which heritability of the trait is to be checked (whether the phenotype is a good reflection of the genotype). Buzza (1995). Production of a new cultivar takes usually more than a decade and it involves also huge funds. the success of a breeding programme therefore will reguire effectiveness in the different steps of breeding (Becker et al., 1999). this necessates the search for quick. cheap and accurate methods of measurement (Buzza, 1995). To increase breeding efficiency it is important to search for traits of indirect selection based on the correlation between primary and secondary traits.

Therefore selection for traits related to $\mathrm{N}$ efficiency could serve as indirect selection criteria to improve $\mathrm{N}$ efficiency in oilseed rape. Since $\mathrm{N}$ efficiency is related both with $\mathrm{N}$ uptake and with $\mathrm{N}$ utilisation. agronomic traits to be measured should be related to either of the two components.

Kessel and Becker (1999b) investigating genetic variation for both uptake and utilisation efficiency in 90 genotypes from different groups (lines, hybrids, old land varieties, resynthesised lines and crosses between Falcon and resynthesised lines) measured the $\mathrm{N}$ content of the dropped leaves. It is characteristic for rapeseed. that leave shading starts very early. already before the end of flowering. The nitrogen in these leaves is lost for yield formation and contributes to the soil $\mathrm{N}$ after harvest which may be leached to the ground water. This trait reacted significant to $\mathrm{N}$ supplys. had a large genetic variation at both $\mathrm{N}$ levels. was highly heritable and negatively correlated with grain yield. and the authors 
therefore concluded that genotypes with improved $\mathrm{N}$ efficiency have low $\mathrm{N}$ content in dropped leaves.

The use of DH lines in indirect selection is promising where grain yield is to be correlated with agronomic traits. As genetically uniform populations they produce better results in biomass harvesting compared to conventional cultivars (Kessel, 2000). Time saving in breeding is a most obvious advantage of $\mathrm{DH}$ lines since yield and other traits could be tested earlier than with conventional cultivars (Kučera et al., 2002).

Kessel (2000) working with a DH population suggested the employment of traits such as thousand seed weight (TSW). flowering interval. plant height and GSL to indirectly select for improved grain yield and consequently improve $\mathrm{N}$ use efficiency.

The best way to investigate genetic correlations is therefore to grow segregating populations of $\mathrm{DH}$ lines under various environments. since these correlations may differ with different $\mathrm{N}$ supply (Gallais, 1984).

In the first part of this thesis (chapter 2) lines of the population Apex x Mohican were investigated. To confirm these results. a second cross. Mansholt x Express was used. where a larger number of $\mathrm{DH}$ lines is available.

\subsection{Materials and Methods:}

In total 99 doubled haploid lines derived from a cross between the two varieties 'Express' and 'Mansholt' and the parents were evaluated in field experiments in four environments in northern Germany. Express is a modern variety whereas Mansholt is an old cultvar .

The environments were: Göttingen-Reinshof in two years (2001/2002). GöttingenDragoneranger in 2001 (experimental stations of the University of Göttingen) and Hohenlieth in the growing season 2001 (experimental station of the breeding company NPZ). The treatments were arranged as 10x10 lattice design at Göttingen-Reinshof. 2001 and Göttingen-Dragoneranger. 2001 but as 11x11 lattice at Göttingen-Reinshof, 2002 (with some 
additional lines not included in this analysis). Three 6x6 lattice experiments were layed in Hohenlieth. 2001. All the experiments were in two replications and two nitrogen levels. The $\mathrm{N}$ levels were: unfertilised (N0) and (240) $\mathrm{kg} \mathrm{N} /$ ha (including $\mathrm{N}_{\min }$ measured in early spring). The fertiliser was applied in two doses: the first portion at the beginning of vegetation early in the year and the second portion four weeks later. Plot size was $3.75 \mathrm{~m}^{2}$ in Göttingen and 13.1 $\mathrm{m}^{2}$ in Hohenlieth.

The agronomic traits measured in the field in Göttingen 2001/2002. were days to begin of flowering (days after $1^{\text {st }}$ April. where about $10 \%$ of the plants in the plots started to flower). end of flowering (days after $1^{\text {st }}$ April where only $10 \%$ of flowers were still in the plot). flowering interval was calculated as the difference between end and begin of flowering. Dropped leaves were also sampled by collecting the freshly shed leaves in the middle of a plot (only in Göttingen-Reinshof and Göttingen-Dragoneranger 2001). the samples were then dried at $60^{\circ} \mathrm{C}$ for several days and then milled using Ultra-centrifugalmilling device ZM 100 (Retsch $\mathrm{GmbH}$ und Co. KG) with 14000 rotations/minute. the samples were passing through a $0.5 \mathrm{~mm}$ screen. For the determination of $\mathrm{N}$ concentration NIRS (Near-Infrared-Reflectance Spectroscopy) was used (Velasco and Möllers 2000).

The plots were harvested at maturity. A sample of 3 gram seed was taken to measure quality traits (oil, protein and glucosolinate) using NIRS, (Reinhardt, 1992). Thousand seed weight (TSW) was calculated from weighing three times 100 seeds. Grain yield. TSW and quality data were measured in all 4 locations.

Analysis of variance was computed using PLABSTAT (Plant Breeding Statistical Programme, UTZ, 1997). N levels were considered fix whereas environments. replications and lines were assumed random.

\section{3 Results}

The mean values of the genotypes for the studied traits at the two $\mathrm{N}$ levels are presented in Table 6. A significant difference between the two $\mathrm{N}$ levels can be observed for yield. protein. 
oil. and GSL content. $\mathrm{N}$ content in dropped leaves and seed $\mathrm{N}$ uptake. The $\mathrm{N}$ levels differ significantly at $\mathrm{P}=10 \%$ for TSW. days to begin and end of flowering. whereas the $\mathrm{N}$ supply had no significant effect on flowering interval.

Table 6: Mean values of 101 genotypes in different $\mathrm{N}$ levels

\begin{tabular}{l|llll}
\hline Traits & Locations & N0 & N240 & mean \\
\hline TSW (g) & 4 & 4.02 & $4.11+$ & 4.06 \\
Yield (dt/ha) & 4 & 34.55 & $51.22^{*}$ & 42.88 \\
Oil (\%) & 4 & 47.29 & $44.89^{* *}$ & 46.09 \\
Protein (\%) & 4 & 18.79 & $21.11^{* *}$ & 19.95 \\
GSL ( $\mu$ mol/seed) & 4 & 50.94 & $54.30^{* *}$ & 52.62 \\
BF (days) & 3 & 27.78 & $29.30+$ & 28.54 \\
EF (days) & 3 & 54.59 & $56.96+$ & 55.78 \\
FI (days) & 3 & 26.81 & 27.66 & 27.24 \\
NDL (\%) & 2 & 0.60 & $1.34^{*}$ & 0.97 \\
SNU (kg N/ha) & 4 & 103.82 & $171.73^{* *}$ & 137.77 \\
\hline
\end{tabular}

+. *. ** Difference between $\mathrm{N}$ levels significant at $\mathrm{P}=0.10 .0 .05 .0 .01$

$\mathrm{BF}=$ days to beginning of flowering; $\mathrm{EF}=$ days to end of flowering; $\mathrm{FI}=$ flowering interval; $\mathrm{NDL}=\mathrm{N}$ in dropped leaves; SNU= Seed $\mathrm{N}$ uptake.

The analysis of variance (Table 7) has shown highly significant genotypic differences in yield. Also the differences between environments and $\mathrm{N}$ levels and the interactions were significant. However. when comparing the variance components. it becomes clear that the size of the interactions between genotypes and $\mathrm{N}$ supply is relatively small (less than $10 \%$ of the genetic variance). There is a relatively large three-factor interaction genotype $\mathrm{x}$ nitrogen $\mathrm{x}$ environment. indicating that there is a different response of genotypes to $\mathrm{N}$ supply depending on the specific environment. (Table 8) for the variance components. has shown a highly significant genotypic variation for all the studied traits except GSL which showed a 
significant variation. $\mathrm{G} \times \mathrm{N}$ interaction was high significant for TSW, oil, protein and GSL. significant for flowering interval and yield.

Table 7: Analysis of variance for grain yield (4 environments)

\begin{tabular}{l|lllll}
\hline Source & DF & SS & $M S$ & Var.comp. & F-value \\
\hline Environment(E) & 3 & 6929.49 & 2309.83 & 11.33 & $105.75^{* *}$ \\
Nitrogen (N) & 1 & 56115.68 & 56115.68 & 131.82 & $19.52^{*}$ \\
Genotypes (G) & 100 & 11556.64 & 115.57 & 11.72 & $5.29^{* *}$ \\
NE & 3 & 8565.93 & 2855.31 & 28.12 & $182.29^{* *}$ \\
GE & 296 & 6465.04 & 21.84 & 3.09 & $1.39^{* *}$ \\
GN & 100 & 1967.18 & 19.67 & 1.00 & $1.26+$ \\
GNE & 296 & 4636.33 & 15.66 & 5.35 & $1.52^{* *}$ \\
Error & 721 & 7437.19 & 10.32 & 10.32 & \\
\hline
\end{tabular}

+. *.** Difference between $\mathrm{N}$ levels significant at $\mathrm{P}=0.10 .0 .05 .0 .01$

Table 8: Variance components for all the traits

\begin{tabular}{|c|c|c|c|c|c|c|c|c|c|c|}
\hline Source & $\begin{array}{l}T S W^{I} \\
(g)\end{array}$ & $\begin{array}{l}\text { Yield }^{I} \\
(d t / h a)\end{array}$ & $\begin{array}{l}O i l^{1} \\
(\%)\end{array}$ & $\begin{array}{l}\text { Protein } \\
(\%)\end{array}$ & $\begin{array}{l}\mathrm{GSL}^{\top} \\
\mu \mathrm{mol} / \mathrm{seed}\end{array}$ & $\begin{array}{l}F^{2} \\
\text { (days) }\end{array}$ & $\begin{array}{l}E F^{2} \\
(\text { days })\end{array}$ & $\begin{array}{l}{F I^{2}} \\
\text { (days) }\end{array}$ & $\begin{array}{l}N D L^{3} \\
(\%)\end{array}$ & $\begin{array}{l}S N U^{I} \\
(\mathrm{kgN} / \mathrm{ha})\end{array}$ \\
\hline $\mathrm{E}$ & $0.02 * *$ & $11.33 * *$ & $4.85 * *$ & $2.73 * *$ & $14.87 * *$ & $32.45 * *$ & $2.46^{* *}$ & $17.83 * *$ & $7.22 * *$ & $124.56^{* *}$ \\
\hline $\mathrm{N}$ & $0.003+$ & $131.82 *$ & $2.81 * *$ & $2.62 * *$ & $5.49 * *$ & $1.08+$ & $2.58+$ & 0.22 & $2813.78^{*}$ & $2251.96 * *$ \\
\hline G & $0.10 * *$ & $11.72 * *$ & $3.15 * *$ & $0.50 * *$ & $221.30 * *$ & $3.47 * *$ & $3.27 * *$ & $1.69 * *$ & $90.80 * *$ & $86.14 * *$ \\
\hline $\mathrm{NE}$ & $0.002 * *$ & $28.12 * *$ & $0.21 * *$ & $0.21 * *$ & $0.59 * *$ & $0.24 * *$ & $0.67 * *$ & $0.40 * *$ & $146.76^{* *}$ & $214.54 * *$ \\
\hline GE & $0.01 * *$ & $3.09 * *$ & $0.32 * *$ & $0.10 * *$ & $5.63 * *$ & $0.41 * *$ & $0.27 *$ & $0.68 * *$ & $27.60 *$ & $17.27+$ \\
\hline GN & $0.001 * *$ & $1.00+$ & $0.14 * *$ & $0.09 * *$ & $1.31 * *$ & 0.01 & 0.17 & $0.15^{*}$ & 5.86 & 6.30 \\
\hline GNE & $0.01 * *$ & $5.35 * *$ & 0.05 & $0.05+$ & $1.14 * *$ & 0.71 & 1.08 & 1.27 & 190.07 & 174.66 \\
\hline
\end{tabular}

+. *. ** Difference between $\mathrm{N}$ levels significant at $\mathrm{P}=0.10 .0 .05 .0 .01$; F-test of respective mean squares $\mathrm{E}=$ Environment. $\mathrm{N}=$ Nitrogen. $\mathrm{G}=$ Genotypes

${ }^{1}$ traits measured in 4 environments. ${ }^{2}$ traits measured in 3 environments. ${ }^{3}$ traits measured in 2 environments $\mathrm{BF}=$ days to beginning of flowering; $\mathrm{EF}=$ days to end of flowering; $\mathrm{FI}=$ flowering interval; $\mathrm{NDL}=\mathrm{N}$ in dropped leaves; SNU= Seed N uptake. 
Distribution of the $\mathrm{DH}$ lines in their grain yield in the two $\mathrm{N}$ levels has shown a wide segregation in yield (Fig. 2). Mansholt was low yielding and Apex was the high yielding parent at both $\mathrm{N}$ levels. most of the $\mathrm{DH}$ lines were intermediate relative to their parents in yield. There is a clear correlation between the two $\mathrm{N}$ levels at $\mathrm{R}^{2}=0.53$ for all the genotypes but $\mathrm{R}^{2}=0.35$ when the 3 very low yielding lines were not included.

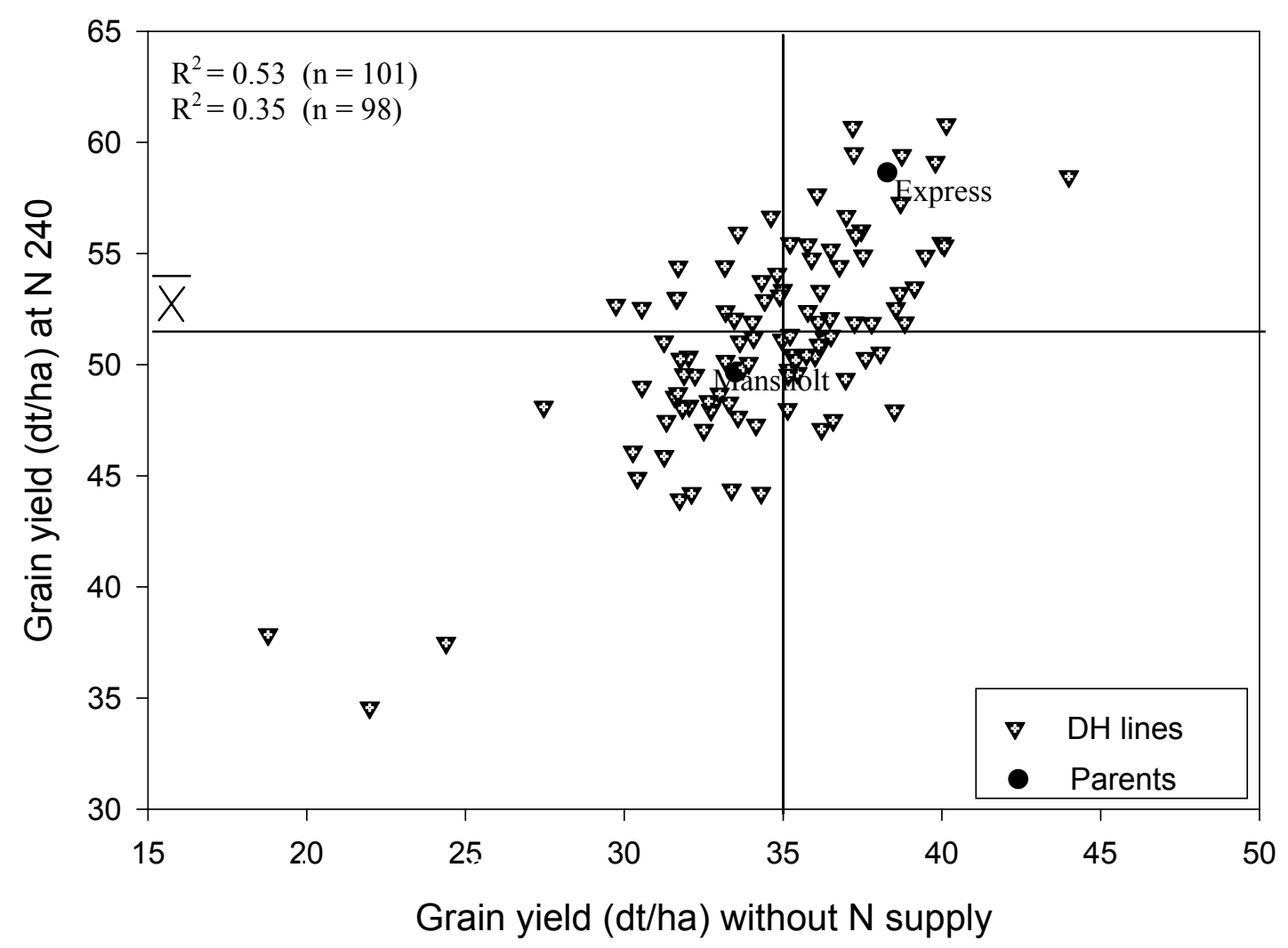

Fig. 2 Grain yield of DH lines in $2 \mathrm{~N}$ levels (4 environments). the lines indicate the mean values

Looking at the correlation of the different traits without $\mathrm{N}$ supply (Table 9). shows that grain yield was positive and highly significantly correlated with seed $\mathrm{N}$ uptake. significantly correlated with days to end of flowering. but highly and negatively correlated protein content. At the high $\mathrm{N}$ supply (Table 10) grain yield remained to be positively and highly correlated with seed $\mathrm{N}$ uptake and negative and highly correlated with protein content but became 
negative and highly significant with $\mathrm{N}$ in dropped leaves and negative and significantly correlated with GSL. Flowering times were no longer correlated with grain yield.

Table 9: Coefficient of correlation for the DH lines in N0 (3 enviroments)

\begin{tabular}{|c|c|c|c|c|c|c|c|c|c|}
\hline Traits & $T K G$ & Yield & Oil & Protein & $G S L$ & $B F$ & $E F$ & $F I$ & $N D L$ \\
\hline Yield & -0.05 & & & & & & & & \\
\hline Oil & -0.19 & 0.00 & & & & & & & \\
\hline Protein & $0.22 *$ & $-0.40 * *$ & $-0.43 * *$ & & & & & & \\
\hline GSL & $-0.20 *$ & -0.19 & 0.05 & 0.14 & & & & & \\
\hline $\mathrm{BF}$ & -0.01 & -0.03 & 0.01 & -0.17 & 0.13 & & & & \\
\hline $\mathrm{EF}$ & -0.01 & $0.20 *$ & -0.06 & $-0.24^{*}$ & -0.03 & $0.69 * *$ & & & \\
\hline FI & 0.00 & $0.29 * *$ & -0.08 & -0.10 & -0.20 & $-0.38 * *$ & $0.41 * *$ & & \\
\hline $\mathrm{NDL}^{1}$ & $-0.35^{* *}$ & 0.16 & 0.10 & -0.04 & -0.07 & 0.00 & -0.07 & -0.09 & \\
\hline SNU & 0.04 & $0.93 * *$ & -0.15 & -0.07 & -0.14 & -0.09 & 0.13 & $0.28 * *$ & 0.16 \\
\hline
\end{tabular}

.$+ *$ ** Difference between $\mathrm{N}$ levels significant at $\mathrm{P}=0.10 .0 .05 .0 .01$

${ }^{1}$ measured at two locations

$\mathrm{BF}=$ days to beginning of flowering; $\mathrm{EF}=$ days to end of flowering; $\mathrm{FI}=$ flowering interval; $\mathrm{NDL}=\mathrm{N}$ in dropped leaves; SNU= Seed N uptake. 
Table 10: Coefficient of correlation for the DH lines in N240 (3 enviroments)

\begin{tabular}{|c|c|c|c|c|c|c|c|c|c|}
\hline Traits & $T K G$ & Yield & Oil & Protein & $G S L$ & $B F$ & $E F$ & $F I$ & $N D L$ \\
\hline Yield & 0.09 & & & & & & & & \\
\hline Oil & -0.12 & 0.03 & & & & & & & \\
\hline Protein & 0.17 & $-0.52 * *$ & $-0.24 *$ & & & & & & \\
\hline GSL & -0.06 & $-0.24^{*}$ & -0.01 & $0.32 * *$ & & & & & \\
\hline $\mathrm{BF}$ & -0.01 & -0.07 & -0.05 & -0.17 & 0.02 & & & & \\
\hline $\mathrm{EF}$ & 0.04 & -0.07 & -0.12 & -0.05 & 0.07 & $0.68 * *$ & & & \\
\hline FI & 0.06 & 0.01 & -0.09 & 0.15 & 0.06 & $-0.43 * *$ & $0.37 * *$ & & \\
\hline $\mathrm{NDL}^{1}$ & $-0.37 * *$ & $-0.33 * *$ & $0.25^{*}$ & 0.09 & -0.04 & 0.02 & -0.11 & -0.15 & \\
\hline SNU & 0.18 & $0.90 * *$ & -0.08 & -0.09 & -0.10 & -0.17 & -0.11 & 0.09 & $-0.33^{* *}$ \\
\hline
\end{tabular}

+ +*.** Difference between $\mathrm{N}$ levels significant at $\mathrm{P}=0.10 .0 .05 .0 .01$

${ }^{1}$ measured at two locations

$\mathrm{BF}=$ days to beginning of flowering; $\mathrm{EF}=$ days to end of flowering; $\mathrm{FI}=$ flowering interval; $\mathrm{NDL}=\mathrm{N}$ in dropped leaves; $\mathrm{SNU}=$ Seed N uptake.

\section{4 Discussion}

This experiment has shown significant $\mathrm{GxN}$ interaction (at $\mathrm{P}=10 \%$ ) for grain yield which has confirmed the results of Möllers et al. (2000) working with modern lines and hybrids and Kessel (2000) working with a DH population from the cross Apex x Mohican in only two environments. We also found the same results having investigated $\mathrm{DH}$ population from the cross Apex x Mohican in seven environments (see chapter 2). Significant GxN interactions were also found for a number of other traits such as protein content. thousand seed weight and flowering interval. The different reaction of the genotypes to $\mathrm{N}$ supply shows the feasibility of the employment of these traits for breeding material adapted to both high and low $\mathrm{N}$ supply. 
Table 11: Correlation of grain yield with some agronomic traits in the $2 \mathrm{~N}$ levels.

\begin{tabular}{l|lccc}
\hline Correlations & \multicolumn{3}{|c}{ Nyikako 2003 } & \multicolumn{2}{c}{ Kessel 2000 } \\
& N0 & $\mathrm{N} 240$ & $\mathrm{~N} 0$ & $\mathrm{~N} 240$ \\
YLD/BF & -0.03 & -0.07 & -0.04 & -0.10 \\
YLD/EF & $0.20^{*}$ & -0.07 & -0.19 & $-0.30^{*}$ \\
YLD/FI & $0.29 * *$ & 0.01 & -0.20 & $-0.27 *$ \\
YLD/ SNU & $0.93 * *$ & $0.90 * *$ & $0.89 *$ & $0.84 * *$ \\
\hline
\end{tabular}

The correlations of grain yield with days to begin of flowering have shown a negative correlation in the two $\mathrm{N}$ levels (statistically not significant). These results were fully in agreement with the findings of Kessel (2000), suggesting that early maturing genotypes will profit from the soil available $\mathrm{N}$ to produce yield not only when soil $\mathrm{N}$ supply is limitted but also under conditions of high $\mathrm{N}$ supply.

We have found a positive and highly significant correlation between yield and days to the end of flowering in low N supply. such an observation was not found by Kessel (2000), we on the other hand could not find a significant correlation between yield and days to the end of flowering at the high $\mathrm{N}$ level. which was observed by Kessel, 2000 to be negative i.e the high yielding genotypes tend to need more days to end of flowering when $\mathrm{N}$ supply is limitted and vice versa under conditions of optimal $\mathrm{N}$ supply (the same is true with flowering interval).

Our findings were again in complete agreement with Kessel (2000). showing the positive significant correlation of yield with seed $\mathrm{N}$ uptake. proving that the $\mathrm{N}$ efficient genotypes will have more $\mathrm{N}$ in the seed at harvest regardless to the $\mathrm{N}$ level.

The above results do suggest that seed $\mathrm{N}$ uptake and protein content could be useful traits in indirect selection due to their high correlation with grain yield in the low $\mathrm{N}$ level $\left(\mathrm{r}=0.90^{* *}\right.$ and $\mathrm{r}=0.52^{* *}$. respectively) and in the high $\mathrm{N}$ supply $\left(\mathrm{r}=0.93 * *\right.$ and $\mathrm{r}=0.40^{* *}$. respectively). 


\section{Genetic variation for $\mathbf{N}$ efficiency in divergent bulks}

\subsection{Introduction}

Breeding for nitrogen efficiency is complex despite the existence of genetic variation for its components due to breeding cost and labour. Therefore identification of morphological or physiological traits related to any of the components of $\mathrm{N}$ efficiency could be a useful approach to select for $\mathrm{N}$ efficiency. however. these traits should be easily measured (Buzza, 1995). such as plant height. seed size. $\mathrm{N}$ concentration in the seed and improved harvest index (Sattelmacher et al., 1995). Ideal morphological traits for nutrient efficiency have been identified with different crops and nutrient elements (Horst et al., 1993; Ma Dwyer, 1998). In order to develop an $\mathrm{N}$ efficient oilseed rape ideotype, it is important to identify traits which could increase either $\mathrm{N}$ uptake. efficient grain yield production or improved $\mathrm{N}$ translocation into the seed. Sattlemacher et al. (1995) have concluded that uptake efficiency could be increased through a well established root system capable of exploring the soil in search of nutrients.

Traditional oilseed rape is characterised by high $\mathrm{N}$ uptake until flowering. low $\mathrm{N}$ uptake during reproductive growth phase and an incomplete $\mathrm{N}$ translocation from vegetative parts to seed resulting in a low $\mathrm{N}$ harvest index (Aufhammer et al., 1994). Wiesler et al. 2001 working on contrasting oilseed ideotypes concluded that the $\mathrm{N}$ efficient ideotype will be the one with improved $\mathrm{N}$ uptake during reproductive growth phase and a high leaf photosynthetic activity. Traits such as high harvest index. low $\mathrm{N}$ in dropped leaves and low seed protein could improve utilisation efficiency. Grami and La Croix (1977) working with spring oilseed rape have reported a direct relationship between high $\mathrm{N}$ uptake and high seed protein content and therefore concluded that selection for high protein should lead to both an improved $\mathrm{N}$ uptake and translocation.

The experimental approach used in this experiment was the testing of 'divergent bulks'. In this approach. a large number of double haploid (DH) lines from a segregating population is 
characterised for traits assumed to be related with $\mathrm{N}$ efficiency. like plant morphology. flowering time. or seed quality. Then about ten lines with lowest or highest expression of the respective trait are bulked (Fig. 3). Such pairs of two divergent bulks each are tested in several environments.

The main advantage of testing divergent bulks compared with testing large populations of DH lines (chapters 2 and 3) is the much smaller number of entries to be tested and consequently the possibility to perform the experiments on a larger number of locations.

In this experiment bulks were produced out of the DH populations of three crosses (Apex $x$ Mohican, Bristol x Lirajet and Mansholt x Express). These bulks were grown in field trials over several locations under two $\mathrm{N}$ levels (N0 and N240 $\mathrm{kg} \mathrm{N} / \mathrm{ha}$ ).

The purpose of this study was to see whether differences among bulks will be related to yield performance at different $\mathrm{N}$ levels which could help in identifying morphological traits to characterise an $\mathrm{N}$ efficient oilseed rape ideotype .

\section{2 Materials and Methods}

\section{2.1 Materials}

Fourty four divergent bulks were produced by mixing doubled haploid lines from three populations derived from crosses between the standard varieties 'Apex' and 'Mohican', 'Bristol' and 'Lirajet' and 'Express' and 'Mansholt'. The mixture in each bulk contained about ten DH lines from the same cross which were selected for extreme expression in a single trait and different in the other traits. There are in total 3 groups of bulks produced from the above $3 \mathrm{DH}$ populations. namely (Table 12):

Cross $1=10$ bulks from the DH population of the cross 'Bristol' and 'Lirajet'

Cross $2=14$ bulks from the DH population of the cross 'Express' and 'Mansholt'.

Cross $3=20$ bulks from the DH population of the cross 'Apex' and 'Mohican'. 
To compose the bulks. the populations (cross 1: 116 lines; cross 2: 98 lines; cross 3: 54 lines) were grown in 2000/2001 in Göttingen-Reinshof and the traits were evaluated as described in Table 12.

\subsubsection{Experimental Locations}

The field trials were carried out in the growing season 2001/2002 in Northern Germany at the following five locations: Göttingen-Reinshof (experimental station of the University of Göttingen). Teendorf (experimental station of the breeding company Semundo). Hohenlieth (experimental station of the breeding company NPZ). Einbeck (experimental station of the breeding company KWS) and Boldebuck (experimental station of the breeding company

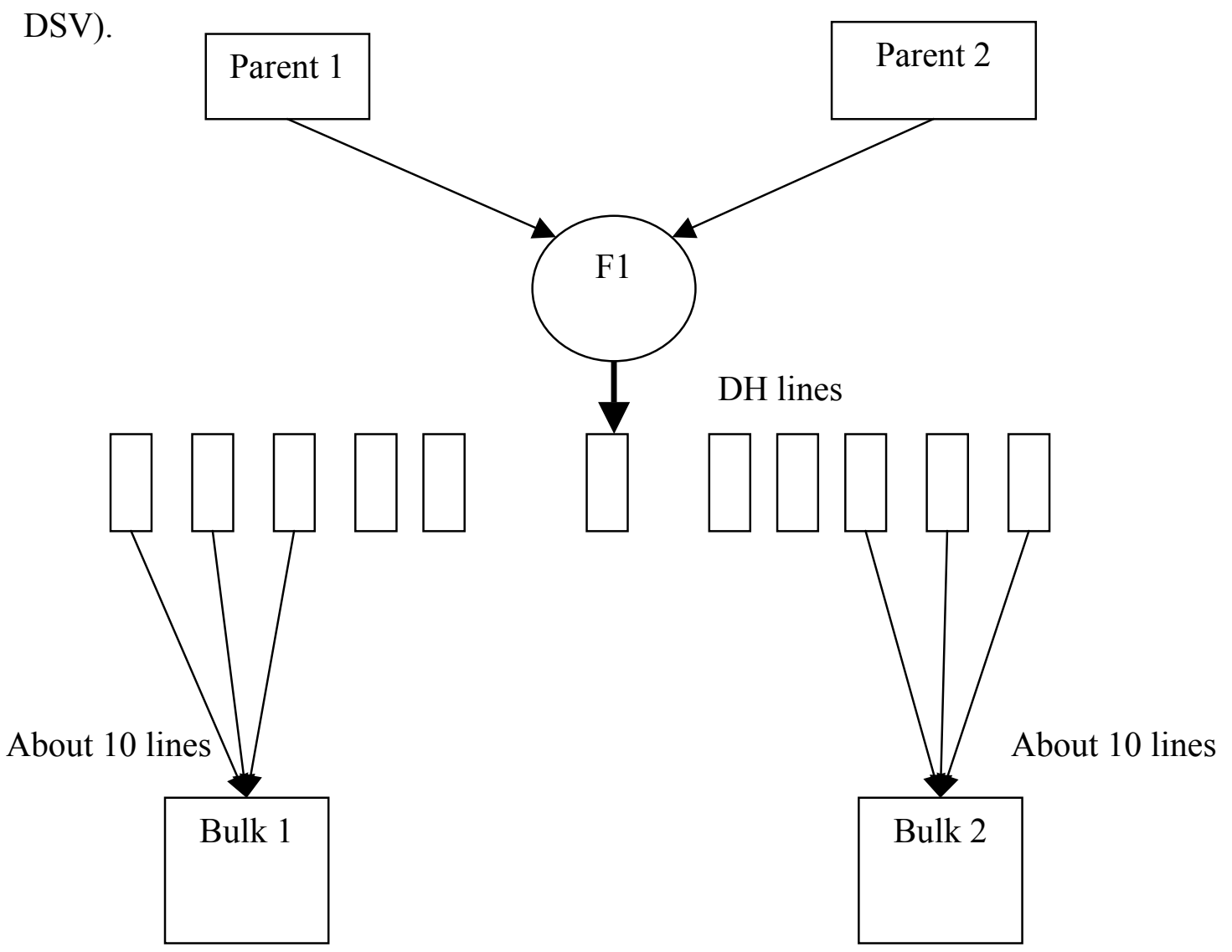

Fig. 3: Production of divergent bulks 
Table 12 : Overview of the genotypes studied

\begin{tabular}{|c|c|c|}
\hline Bulk Number & Trait & Population \\
\hline 1 & Thin stem $^{1}$ & Bristol x Lirajet \\
\hline 2 & Thick stem &.. \\
\hline 3 & Tall $^{1}$ & .. \\
\hline 4 & Short & .. \\
\hline 5 & Early maturing $^{1}$ & .. \\
\hline 6 & Late maturing & .. \\
\hline 7 & High protein ${ }^{2}$ & .. \\
\hline 8 & Low protein & .. \\
\hline 9 & High oil $^{2}$ & .. \\
\hline 10 & Low oil & .. \\
\hline 11 & Branching type ${ }^{1}$ & Express x Mansholt \\
\hline 12 & low-branching type & .. \\
\hline 13 & Short $^{1}$ & .. \\
\hline 14 & Tall & .. \\
\hline 15 & High oil $^{2}$ & .. \\
\hline 16 & Low oil & .. \\
\hline 17 & High protein ${ }^{2}$ & .. \\
\hline 18 & Low protein & .. \\
\hline 19 & High TSW ${ }^{3}$ & .. \\
\hline 20 & Low TSW & .. \\
\hline 21 & Early Flowering $^{1}$ & .. \\
\hline 22 & Late Flowering & .. \\
\hline 23 & High N-dropped leaves ${ }^{2}$ & .. \\
\hline 24 & low N-dropped leaves & \\
\hline 25 & High oil $^{2}$ & Apex x Mohican \\
\hline 26 & Low oil & .. \\
\hline 27 & High protein ${ }^{2}$ & .. \\
\hline 28 & Low protein & .. \\
\hline 29 & Early Flowering $^{1}$ & .. \\
\hline 30 & Late Flowering & .. \\
\hline 31 & Tall $^{1}$ & .. \\
\hline 32 & Short & .. \\
\hline 33 & High $\mathrm{LAI}^{4}$ & .. \\
\hline 34 & Low LAI & .. \\
\hline 35 & High $\mathrm{N}-$ dropped leaves ${ }^{2}$ & .. \\
\hline 36 & low N-dropped leaves & .. \\
\hline 37 & High dry weight (end of flowering) ${ }^{5}$ & .. \\
\hline 38 & Low dry weight (end of flowering) & .. \\
\hline 39 & High $\mathrm{HI}^{5}$ & .. \\
\hline 40 & Low HI & .. \\
\hline 41 & High TSW ${ }^{3}$ & .. \\
\hline 42 & Low TSW ${ }^{2}$ & .. \\
\hline 43 & High N-straw & .. \\
\hline 44 & Low N-straw & .. \\
\hline Standard cultivar & Apex & _ \\
\hline Standard cultivar & Mohican & - \\
\hline Standard cultivar & Bristol & - \\
\hline Standard cultivar & Lirajet & - \\
\hline Standard cultivar & Express & \\
\hline $\begin{array}{l}\text { 1: scoring (indepe } \\
\text { 2: measured by } \mathrm{N} \\
\text { 3: measured by cc } \\
\text { 4: data provided b } \\
\text { 5: data from the e }\end{array}$ & $\begin{array}{l}\text { y two persons) } \\
\times 100 \text { seeds } \\
\text { Niesler. University of Hannover } \\
\text { in chapter one }\end{array}$ & \\
\hline
\end{tabular}




\subsubsection{Methods}

The treatments were arranged as $7 \times 7$ lattice design in all the locations except in Boldebuck where two experiments were laid down as 6x5 lattice. All the experiments were in two replications and two nitrogen levels. The $\mathrm{N}$ levels were: unfertilised (N0) and $240 \mathrm{~kg} \mathrm{~N} / \mathrm{ha}$ (including $\mathrm{N}_{\min }$ in early spring). The fertiliser was applied in two doses: the first portion at the beginning of vegetation early in the year and the second portion four weeks later. Plot size was $11.25 \mathrm{~m}^{2}$ in Göttingen and Einbeck. $15 \mathrm{~m}^{2}$ in Teendorf, $13.1 \mathrm{~m}^{2}$ in Hohenlieth and $19 \mathrm{~m}^{2}$ in Boldebuck.

Plant height at the end of flowering (the height in $\mathrm{cm}$ from soil surface to the plant tip) was measured in all the 5 locations as well as grain yield at maturity.

Plants were sampled for above ground biomass and $\mathrm{N}$ content at end of flowering stage of growth in Göttingen and Einbeck. where plants within $1 \mathrm{~m}^{2}$ each plot (excluding border rows) were cut off at ground level. after determining the total fresh weight. representative samples were dried for several days at $60^{\circ} \mathrm{C}$ to calculate dry weight. The samples were then milled passing through a $0.5 \mathrm{~mm}$ screen for the determination of $\mathrm{N}$ concentration using NIRS (Near-Infrared-Reflectance-Spectroscopy) according to Velasco and Möllers (2000).

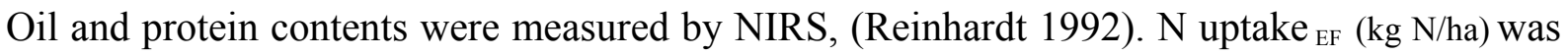
calculated by multiplying $\mathrm{N}$ concentration in the straw at end of flowering with straw dry weight at the end of flowering.

\subsubsection{Statistical analysis}

Analysis of variance was computed using PLABSTAT (Plant Breeding Statistical Programme, UTZ, 1997). N levels were considered fixed whereas environments. replications and lines were assumed random. 


\section{3 Results}

The general overview of the traits studied in the three crosses in two $\mathrm{N}$ levels are presented in Tables 13, 14 and 15. The genotypes of crosss 1 have shown a significant genotypic variation for grain yield at $\mathrm{P}=10 \%$ without $\mathrm{N}$ supply and a significant variation at the high $\mathrm{N}$ level as well as on the average. This variation in the yield was accompanied by a significant variation at $\mathrm{P}=10 \%$ in plant height. highly significant variation for protein content and dry matter at end of flowering and a significant variation for oil content at sub-optimal $\mathrm{N}$ supply.

The variation was the same at the high $\mathrm{N}$ supply except that the variation for grain yield was significant and dry matter production was not any more significant. however. on the average $\mathrm{N}$ supply the genotypes were significantly different in grain yield but highly significant variation was observed for plant height. oil and protein content (Table 13).

Cross 2 has shown genetic variation only for oil content in the different $\mathrm{N}$ levels (Table 14).

The genotypes in cross 3 have shown significant genotypic variation for oil content and a highly significant variation for protein content at the sub-optimal $\mathrm{N}$ upply. At the high $\mathrm{N}$ level as well as at the average $\mathrm{N}$ supply there was highly significant variation for both oil and protein content and a significant variation for plant height (Table 15).

Table 13: Mean values of divergent bulks from cross 1 at different $\mathrm{N}$ levels

\begin{tabular}{l|lllllll}
\hline N level & DWSEF & Nuptake & Pl height & Yield & Oil & Protein & SNU \\
& $d t / h a$ & $k g N / h a$ & $c m$ & $d t / h a$ & $\%$ & $\%$ & $\mathrm{~kg} \mathrm{~N} / \mathrm{ha}$ \\
& $(2$ Loc. $)$ & $(2$ Loc. $)$ & $(5$ Loc. $)$ & $(5$ Loc. $)$ & $(4$ Loc. $)$ & $(4$ Loc. $)$ & (4 Loc.) \\
\hline N0 & $71.97^{* *}$ & 138.57 & $146.16^{+}$ & $28.72+$ & $50.79^{*}$ & $17.47^{* *}$ & 93.57 \\
N240 & 123.25 & 292.25 & $163.48^{*}$ & $37.08^{*}$ & $48.01^{*}$ & $19.96^{* *}$ & 132.55 \\
Mean & 97.61 & 215.41 & $155.32^{* *}$ & $32.90^{*}$ & $49.40^{* *}$ & $18.72^{* *}$ & 113.06 \\
\hline
\end{tabular}

+. *.** Significant variation among genotypes 
Table 14: Mean values of divergent bulks from cross 2 at different $\mathrm{N}$ levels

\begin{tabular}{l|lllllll}
\hline N level & DWSEF & Nuptake & Pl height & Yield & Oil & Protein & SNU \\
& $d t / h a$ & $k g N / h a$ & $c m$ & $d t / h a$ & $\%$ & $\%$ & $\mathrm{~kg} \mathrm{~N} / \mathrm{ha}$ \\
& $(2$ Loc. $)$ & $(2$ Loc. $)$ & $(4$ Loc. $)$ & $(4$ Loc. $)$ & $(3$ Loc. $)$ & $(3$ Loc.) & (3 Loc.) \\
\hline N0 & 74.07 & 137.48 & 139.13 & 31.38 & $51.91^{* *}$ & 19.00 & 112.69 \\
N240 & 117.31 & 275.08 & 150.44 & 40.10 & $48.70^{* *}$ & 21.90 & 161.32 \\
Mean & $95.69+$ & 206.46 & 144.78 & 35.74 & $50.31^{* *}$ & 20.45 & 137.00 \\
\hline
\end{tabular}

+. *.** Significant variation among genotypes

Table 15: Mean values of divergent bulks from cross 3 at different $\mathrm{N}$ levels

\begin{tabular}{l|lllllll}
\hline N level & DWSEF & Nuptake & Pl height & Yield & Oil & Protein & $S N U$ \\
& $d t / h a$ & $k g N / h a$ & $\mathrm{~cm}$ & $d t / h a$ & $\%$ & $\%$ & $\mathrm{~kg} \mathrm{~N} / \mathrm{ha}$ \\
& $(2$ Loc. $)$ & $(2$ Loc. $)$ & $(5$ Loc. $)$ & $(5$ Loc. $)$ & $(4$ Loc. $)$ & (4 Loc.) & (4 Loc.) \\
\hline N0 & 74.47 & 139.59 & 142.46 & 32.98 & $50.76^{*}$ & $17.59^{* *}$ & 108.52 \\
N240 & 126.63 & 293.24 & $158.92^{*}$ & 43.03 & $47.65^{* *}$ & $20.32^{* *}$ & 156.94 \\
Mean & 100.55 & 216.41 & $150.69^{*}$ & 38.00 & $49.20^{* *}$ & $18.96^{* *}$ & 132.73 \\
\hline
\end{tabular}

+. *. ** Significant variation among genotypes

Tables of analysis of variance (ANOVA) for grain yield have shown genotypic variation only in cross 1 (Tables 16. 17 and 18). The GxN interaction was not significant in any of these crosses.

Table 16: Analysis of variance for grain yield in cross 1 (5 environments)

\begin{tabular}{l|lllll}
\hline Source & DF & SS & MS & Var.comp & F-value \\
\hline Environment (E) & 4 & 16754.71 & 4188.68 & 209.00 & $488.66^{* *}$ \\
Genotypes (G) & 9 & 342.10 & 38.11 & 2.48 & $2.86^{*}$ \\
Nitrogen (N) & 1 & 1747.07 & 1747.07 & 33.91 & $33.75^{* *}$ \\
GE & 36 & 479.20 & 13.31 & 2.37 & $1.55+$ \\
GN & 9 & 83.71 & 9.30 & 0.15 & 1.09 \\
EN & 4 & 207.05 & 51.76 & 4.32 & $6.04^{* *}$ \\
GEN & 36 & 308.58 & 8.57 & 8.57 & \\
\hline
\end{tabular}


Table 17: Analysis of variance for grain yield in cross 2 (4 environments)

\begin{tabular}{l|lllll}
\hline Source & DF & SS & MS & Var.comp & F-value \\
\hline Environment(E) & 3 & 17663.30 & 5887.77 & 209.85 & $486.09^{* *}$ \\
Genotypes(G) & 13 & 328.74 & 25.29 & 0.79 & 1.33 \\
Nitrogen(N) & 1 & 2130.12 & 2130.12 & 35.19 & $13.37^{*}$ \\
GE & 39 & 741.00 & 19.00 & 3.44 & $1.57+$ \\
GN & 13 & 134.98 & 10.38 & -0.43 & 0.86 \\
EN & 3 & 477.83 & 159.28 & 10.51 & $13.15^{* *}$ \\
GEN & 39 & 472.38 & 12.11 & 12.11 & \\
\hline
\end{tabular}

+. *.** Significant variation among genotypes

Table 18: Analysis of variance for grain yield in cross 3 (5 environments)

\begin{tabular}{l|lllll}
\hline Source & DF & SS & MS & Var.comp & F-value \\
\hline Environment(E) & 4 & 42828.85 & 10707.21 & 267.53 & $1825.71^{* *}$ \\
Genotypes(G) & 19 & 357.64 & 18.82 & -0.25 & 0.88 \\
Nitrogen(N) & 1 & 5050.53 & 5050.53 & 47.45 & $16.56^{*}$ \\
GE & 76 & 1619.97 & 21.32 & 7.73 & $3.63^{* *}$ \\
GN & 19 & 138.24 & 7.28 & 0.28 & 1.24 \\
EN & 4 & 1220.17 & 305.04 & 14.96 & $52.01^{* *}$ \\
GEN & 76 & 445.72 & 5.86 & 5.86 & \\
\hline
\end{tabular}

+. *.** Significant variation among genotypes

mean squares of the studied traits in cross 1 at the two $\mathrm{N}$ levels has shown a highly significant genotypic variation for plant height. oil and protein content and a significant genotypic variation for grain yield (Table 19). 
Table 19: Mean squares of the genotypes in cross 1 at two $\mathrm{N}$ levels

\begin{tabular}{|c|c|c|c|c|c|c|c|}
\hline genotypes & $\begin{array}{l}\text { DWSEF } \\
d t / h a \\
\text { (2 Loc.) }\end{array}$ & $\begin{array}{l}\text { Nuptake }_{E F} \\
\mathrm{~kg} \mathrm{~N} / \mathrm{ha} \\
\text { (2 Loc.) }\end{array}$ & $\begin{array}{l}\text { Pl height } \\
\mathrm{cm} \\
\text { (5 Loc.) }\end{array}$ & $\begin{array}{l}\text { Yield } \\
d t / h a \\
\text { (5 Loc.) }\end{array}$ & $\begin{array}{l}\text { Oil } \\
\% \\
\text { (4 Loc.) }\end{array}$ & $\begin{array}{l}\text { Protein } \\
\% \\
\text { (4 Loc.) }\end{array}$ & $\begin{array}{l}S N U \\
\quad \mathrm{~kg} \mathrm{~N} / \mathrm{ha} \\
\text { (4 Loc.) }\end{array}$ \\
\hline Environment (E) & 3.59 & $61287.75^{* *}$ & $737.88 * *$ & $4188.68 * *$ & $53.85^{* *}$ & $7.47 * *$ & $32641.43 * *$ \\
\hline Genotypes (G) & 54.27 & 635.89 & $125.59 * *$ & $38.11^{*}$ & $2.11 * *$ & $1.76^{* *}$ & 122.50 \\
\hline Nitrogen $(\mathrm{N})$ & 26294.33 & $236167.74+$ & $6655.95 * *$ & $1747.07 * *$ & $154.60 * *$ & $123.43^{*}$ & $30392.32 *$ \\
\hline GE & 54.91 & 950.91 & $35.32+$ & $13.31+$ & 0.51 & 0.19 & 137.96 \\
\hline GN & 111.42 & 899.98 & 4.95 & 9.30 & 0.25 & 0.15 & 64.28 \\
\hline EN & 952.97 & 353.61 & $174.78 * *$ & $51.76^{* *}$ & $2.86^{* *}$ & $5.08 * *$ & $1625.55 * *$ \\
\hline GEN & 69.26 & 577.95 & 20.73 & 8.57 & 0.32 & 0.17 & 135.00 \\
\hline
\end{tabular}

+. *.** Significant variation among genotypes

mean squares of the studied traits in cross 2 at the two $\mathrm{N}$ levels has shown a highly significant genotypic variation for oil content and a significant variation at $\mathrm{P}=10 \%$ for dry matter production at the end of flowering (Table 20).

Table 20: Mean squares of the genotypes in cross 2 at two N levels

\begin{tabular}{|c|c|c|c|c|c|c|c|}
\hline genotypes & $\begin{array}{l}\text { DWSEF } \\
d t / h a \\
\text { (2 Loc.) }\end{array}$ & $\begin{array}{l}\text { Nuptake }_{E F} \\
\mathrm{~kg} \mathrm{~N} / \mathrm{ha} \\
\text { (2 Loc.) }\end{array}$ & $\begin{array}{l}\text { Pl height } \\
\mathrm{cm} \\
\text { (4 Loc.) }\end{array}$ & $\begin{array}{l}\text { Yield } \\
d t / h a \\
\text { (4 Loc.) }\end{array}$ & $\begin{array}{l}\text { Oil } \\
\% \\
(3 \text { Loc.) }\end{array}$ & $\begin{array}{l}\text { Protein } \\
\% \\
(3 \text { Loc.) }\end{array}$ & $\begin{array}{l}S N U \\
\quad \mathrm{~kg} \mathrm{~N} / \mathrm{ha} \\
\text { (3 Loc.) }\end{array}$ \\
\hline Environment (E) & 0.48 & $66874.30^{* *}$ & $1097.31 * *$ & $5887.77 * *$ & $67.03^{* *}$ & $27.51^{* *}$ & $27443.23^{* *}$ \\
\hline Genotypes (G) & $360.77+$ & 1402.14 & 37.55 & 25.29 & $7.94 * *$ & 0.35 & 213.70 \\
\hline Nitrogen $(\mathrm{N})$ & 26168.85 & $263710.77+$ & $3581.54 * *$ & $2130.12 *$ & $216.07 * *$ & $176.32^{*}$ & $49666.79+$ \\
\hline GE & 165.16 & 946.58 & $33.81^{*}$ & $19.00+$ & $0.33+$ & 0.24 & 133.66 \\
\hline GN & 98.31 & 521.47 & 12.88 & 10.38 & 0.11 & 0.05 & 94.73 \\
\hline EN & $719.58^{*}$ & 450.82 & 17.83 & $159.28 * *$ & $1.89 * *$ & $6.48 * *$ & $4077.84 * *$ \\
\hline GEN & 141.58 & 879.03 & 16.83 & 12.11 & 0.19 & 0.18 & 142.17 \\
\hline
\end{tabular}


in cross three there was a highly significant variation for both oil and protein content as well as a significant variation for plant height (Table 21). The mean squares has shown no genotypic variation for grain yield in cross 2 and 3.

Table 21: Mean squares of the genotypes in cross 3 at two $\mathrm{N}$ levels

\begin{tabular}{|c|c|c|c|c|c|c|c|}
\hline genotypes & $\begin{array}{l}\text { DWSEF } \\
d t / h a \\
(2 \text { Loc.) }\end{array}$ & $\begin{array}{l}\text { Nuptake }_{E F} \\
\mathrm{~kg} \mathrm{~N} / \mathrm{ha} \\
\text { (2 Loc.) }\end{array}$ & $\begin{array}{l}\text { Pl height } \\
\mathrm{cm} \\
\text { (5 Loc.) }\end{array}$ & $\begin{array}{l}\text { Yield } \\
d t / h a \\
\text { (5 Loc.) }\end{array}$ & $\begin{array}{l}\text { Oil } \\
\% \\
\text { (4 Loc.) }\end{array}$ & $\begin{array}{l}\text { Protein } \\
\% \\
\text { (4 Loc.) }\end{array}$ & $\begin{array}{l}\text { SNU } \\
k g N / h a \\
\text { (4 Loc.) }\end{array}$ \\
\hline Environment (E) & 0.82 & $122417.43^{* *}$ & $1138.48^{* *}$ & $10707.21^{* *}$ & $80.58^{* *}$ & $23.99^{* *}$ & $73931.00 * *$ \\
\hline Genotypes (G) & 89.45 & 478.97 & $64.56^{*}$ & 18.82 & $1.66^{* *}$ & $1.09 * *$ & 122.54 \\
\hline Nitrogen $(\mathrm{N})$ & $54400.27+$ & $472212.54+$ & $13534.73 * *$ & $5050.53 *$ & $387.32 * *$ & $299.15^{*}$ & $93777.43 *$ \\
\hline GE & 245.13 & 1690.44 & $35.81 *$ & $21.32 * *$ & $0.57 * *$ & $0.28+$ & $192.33 * *$ \\
\hline GN & 203.25 & 1264.86 & 20.97 & 7.28 & 0.32 & 0.29 & 101.28 \\
\hline EN & $952.82 *$ & 922.35 & $215.54 * *$ & $305.04 * *$ & $6.48^{*}$ & $10.70^{* *}$ & $6341.32 * *$ \\
\hline GEN & 186.41 & 966.78 & 23.35 & 5.86 & 0.26 & 0.20 & 73.53 \\
\hline
\end{tabular}

+. *.** Significant variation among genotypes

(Table 22) presenting the mean performance of the genotypes in cross 1 at the low $\mathrm{N}$ supply has shown statistical differences among high and low protein bulks. tall and short bulks and thin and thick stemed bulks for dry matter production at the end of flowering. where genotypes with high protein content. tall and with thick stems had higher dry matter production. Tall plants with thick stems had high grain yields and were high in oil content. 
Table 22: Mean values of individual bulks in cross 1 without $\mathrm{N}$ supply

\begin{tabular}{l|llllllc}
\hline Genotypes & DWSEF & Nuptake $_{E F}$ & Pl height & Yield & Oil & Protein & SNU \\
& $d t / h a$ & $k g N / h a$ & $c m$ & $d t / h a$ & $\%$ & $\%$ & kg N/ha \\
& $(2$ Loc.) & $(2$ Loc.) & $(5$ Loc.) & $(5$ Loc.) & (4 Loc.) & (4 Loc.) & (4 Loc.) \\
\hline Thin stem & $\mathbf{5 9 . 7 4}$ & 113.62 & 145.72 & $\mathbf{2 6 . 7 8}$ & 50.33 & H 17.66 & 89.75 \\
Thick stem & $\mathbf{6 9 . 6 4}$ & 139.21 & 151.02 & $\mathbf{3 0 . 4 9}$ & 51.31 & L 17.16 & 96.82 \\
Tall & $\mathbf{8 3 . 5 1}$ & 159.23 & 148.65 & $\mathbf{3 0 . 7 6}$ & $\mathbf{5 1 . 2 4}$ & L 17.30 & 90.84 \\
Short & $\mathbf{7 0 . 1 7}$ & 137.41 & 141.66 & $\mathbf{2 5 . 6 4}$ & $\mathbf{5 0 . 0 0}$ & H 17.90 & 87.06 \\
Early maturing & 75.85 & 141.24 & 144.35 & 29.37 & 49.84 & H 17.78 & 98.72 \\
Late maturing & 73.85 & 137.74 & 154.46 & 30.02 & 50.78 & L 17.15 & 97.07 \\
High protein & $\mathbf{7 9 . 2 7}$ & 160.83 & 148.16 & 28.58 & 51.10 & H 17.81 & 92.38 \\
Low protein & $\mathbf{6 5 . 2 9}$ & 137.76 & 143.34 & 28.45 & 51.16 & L 16.97 & 90.48 \\
High oil & 73.21 & 128.43 & 147.41 & 30.07 & $\mathbf{5 1 . 6 9}$ & L 16.78 & 90.79 \\
Low oil & 69.15 & 130.24 & 146.88 & 27.00 & $\mathbf{5 0 . 4 6}$ & H 18.22 & 101.79 \\
LSD 0.05 & 8.75 & 42.14 & 7.65 & 3.63 & 1.03 & 0.65 & 17.21 \\
& & & & & & & \\
5 high protein (H) & 70.84 & 136.67 & 145.35 & 27.47 & 50.35 & 17.87 & 93.94 \\
5 low protein (L) & 73.10 & 140.47 & 148.98 & 29.96 & 51.24 & 17.07 & 93.20 \\
\hline
\end{tabular}

(Bold: differences between divergent bulks statistically significant)

The variation for the same cross at high $\mathrm{N}$ supply has shown statistically significant differences among tall and short bulks for plant height and protein content where tall plants had low protein content. like in the sub-optimal $\mathrm{N}$ supply the plants with thick stem also had high grain yields. late maturing had low protein content (Table 23).

At the average $\mathrm{N}$ supply (Table 24) it is clearly seen that the tall. late maturing and thick stemmed genotypes in cross 1 had low protein content but high grain yields. 
Table 23: Mean values of individual bulks in cross 1 at high $\mathrm{N}$ supply

\begin{tabular}{l|lllllll}
\hline Genotypes & DWSEF & Nuptake $_{E F}$ & Pl height & Yield & Oil & Protein & SNU \\
& $d t / h a$ & $k g N / h a$ & $c m$ & $d t / h a$ & $\%$ & $\%$ & $k g N / h a$ \\
& $(2$ Loc.) & $(2$ Loc.) & $(5$ Loc.) & $(5$ Loc.) & (4 Loc.) & (4 Loc.) & (4 Loc.) \\
\hline Thin stem & 121.18 & 295.33 & 162.88 & $\mathbf{3 2 . 3 8}$ & 47.91 & H 20.09 & 122.12 \\
Thick stem & 132.33 & 322.90 & 167.26 & $\mathbf{3 9 . 7 2}$ & 48.30 & L 19.60 & 136.73 \\
Tall & 122.09 & 291.30 & $\mathbf{1 6 6 . 5 3}$ & 37.76 & 48.16 & L 19.60 & 127.76 \\
Short & 122.81 & 330.63 & $\mathbf{1 5 6 . 6 7}$ & 35.07 & 47.76 & H 20.69 & 132.41 \\
Early maturing & 126.96 & 306.60 & 161.80 & 34.11 & 47.10 & H 20.50 & 128.73 \\
Late maturing & 123.46 & 263.45 & 168.45 & 38.61 & 48.45 & L 19.42 & 135.25 \\
High protein & 113.67 & 257.62 & 162.36 & 37.61 & 47.77 & H 20.61 & 133.49 \\
Low protein & 130.89 & 293.65 & 160.59 & 38.91 & 48.35 & L 19.45 & 134.79 \\
High oil & 114.62 & 269.35 & 164.44 & 40.09 & 48.67 & L 19.48 & 137.90 \\
Low oil & 124.46 & 291.66 & 163.82 & 36.51 & 47.64 & H 20.16 & 136.35 \\
LSD 0.05 & 23.64 & 77.77 & 5.81 & 4.78 & 0.83 & 0.57 & 16.68 \\
& & & & & & & \\
5 high protein (H) & 121.82 & 296.37 & 161.51 & 35.14 & 47.64 & 20.41 & 130.62 \\
5 low protein (L) & 124.68 & 288.13 & 165.45 & 39.02 & 48.39 & 19.51 & 134.49 \\
\hline
\end{tabular}

(Bold: differences between divergent bulks statistically significant)

Table 24: Mean values of individual bulks in cross 1 . average of two $\mathrm{N}$ levels

\begin{tabular}{l|lllllll}
\hline Genotypes & DWSEF & Nuptake $_{E F}$ & Pl height & Yield & Oil & Protein & SNU \\
& $d t / h a$ & $k g N / h a$ & $c m$ & $d t / h a$ & $\%$ & $\%$ & $k g N / h a$ \\
& $(2$ Loc.) & $(2$ Loc.) & $(5$ Loc.) & $(5$ Loc.) & (4 Loc.) & (4 Loc.) & (4 Loc.) \\
\hline Thin stem & 90.46 & 204.48 & 154.30 & $\mathbf{2 9 . 5 8}$ & 47.91 & H 18.87 & 105.93 \\
Thick stem & 100.99 & 231.06 & 159.14 & $\mathbf{3 5 . 1 1}$ & 48.30 & L 18.38 & 116.77 \\
Tall & 102.80 & 225.26 & $\mathbf{1 5 7 . 5 9}$ & $\mathbf{3 4 . 2 6}$ & 48.16 & L 18.45 & 109.30 \\
Short & 96.49 & 234.02 & $\mathbf{1 4 9 . 1 6}$ & $\mathbf{3 0 . 3 5}$ & 47.76 & H 19.30 & 109.73 \\
Early maturing & 101.41 & 223.92 & $\mathbf{1 5 3 . 0 7}$ & 31.74 & $\mathbf{4 7 . 1 0}$ & H 19.14 & 113.73 \\
Late maturing & 98.66 & 200.60 & $\mathbf{1 6 1 . 4 6}$ & 34.31 & $\mathbf{4 8 . 4 5}$ & L 18.28 & 116.16 \\
High protein & 96.47 & 209.23 & 155.26 & 33.10 & 47.77 & H 19.21 & 112.93 \\
Low protein & 98.08 & 215.70 & 151.97 & 33.68 & 48.35 & L 18.21 & 112.64 \\
High oil & 93.91 & 198.89 & 155.92 & $\mathbf{3 5 . 0 8}$ & $\mathbf{4 8 . 6 7}$ & L 18.13 & 114.35 \\
Low oil & 96.81 & 210.95 & 155.35 & $\mathbf{3 1 . 7 6}$ & $\mathbf{4 7 . 6 4}$ & H 19.19 & 119.07 \\
LSD 0.05 & 11.85 & 49.33 & 5.39 & 3.31 & 0.73 & 0.45 & 12.05 \\
& & & & & & & \\
5 high protein (H) & 96.33 & 216.52 & 153.43 & 31.31 & 47.64 & 19.14 & 112.22 \\
5 low protein (L) & 98.89 & 214.18 & 157.22 & 34.49 & 48.39 & 18.29 & 113.84 \\
\hline
\end{tabular}

(Bold: differences between divergent bulks statistically significant) 
Mean values of the bulks in cross 2 without $\mathrm{N}$ supply has shown that the late maturing genotypes had high dry matter production at the end of flowering and were low in protein content. Bold seeds were low in oil content and these two bulks were high in grain yield. though grain yields were statistically not significant (Table 25).

The same variation was observed for the same cross at high $\mathrm{N}$ level except the fact that differences in TSW was not any longer statistically significant (Table 26).

Table 25: Mean values of individual bulks in cross 2 without $\mathrm{N}$ supply

\begin{tabular}{|c|c|c|c|c|c|c|c|}
\hline Genotypes & $\begin{array}{l}\text { DWSEF } \\
d t / h a \\
(2 \text { Loc.) }\end{array}$ & $\begin{array}{l}\text { Nuptake }_{E F} \\
\mathrm{~kg} \mathrm{~N} / \mathrm{ha} \\
\text { (2 Loc.) }\end{array}$ & $\begin{array}{l}\text { Pl height } \\
\mathrm{cm} \\
\text { (4 Loc.) }\end{array}$ & $\begin{array}{l}\text { Yield } \\
d t / h a \\
\text { (4 Loc.) }\end{array}$ & $\begin{array}{l}\text { Oil } \\
\% \\
(3 \text { Loc.) }\end{array}$ & $\begin{array}{l}\text { Protein } \\
\% \\
(3 \text { Loc. })\end{array}$ & $\begin{array}{l}S N U \\
\quad k g N / h a \\
\text { (3 Loc.) }\end{array}$ \\
\hline Branching type & 75.00 & 132.45 & 137.29 & 32.93 & 50.13 & L 18.97 & 119.01 \\
\hline Low branching type & 66.35 & 109.09 & 138.43 & 30.43 & 50.69 & H 19.03 & 107.90 \\
\hline Short & 76.76 & 144.55 & 138.32 & 32.89 & 52.40 & H 19.07 & 115.68 \\
\hline Tall & 78.68 & 147.97 & 138.22 & 31.08 & 51.87 & L 18.89 & 116.67 \\
\hline High oil & 60.86 & 121.15 & 137.93 & 30.16 & 54.44 & L 18.74 & 107.68 \\
\hline Low oil & 71.43 & 141.94 & 136.93 & 30.59 & 49.89 & H 19.03 & 110.86 \\
\hline High protein & 78.44 & 158.22 & 139.33 & 31.67 & 52.45 & H 19.34 & 114.45 \\
\hline Low protein & 82.93 & 150.00 & 140.08 & 33.60 & 51.87 & L 18.75 & 121.39 \\
\hline High TSW & 80.39 & 146.13 & 143.73 & 31.13 & 51.55 & H 19.01 & 110.98 \\
\hline Low TSW & 68.24 & 125.03 & 139.20 & 28.63 & $\mathbf{5 2 . 5 7}$ & L 18.96 & 102.62 \\
\hline Early flowering & 62.74 & 116.38 & 135.75 & 29.63 & 51.76 & Н 19.69 & 108.58 \\
\hline Late flowering & 83.00 & 150.84 & 144.07 & 32.69 & 52.83 & L 18.75 & 117.81 \\
\hline High $\mathrm{N}$ d. leaves & 73.76 & 137.28 & 137.37 & 31.48 & 51.88 & H 19.05 & 110.45 \\
\hline Low $\mathrm{N}$ d. leaves & 78.43 & 148.71 & 141.13 & 32.36 & 52.42 & L 18.71 & 113.56 \\
\hline LSD 0.05 & 16.9 & 36.8 & 7.2 & 3.7 & 0.9 & 0.8 & 14.0 \\
\hline 7 high protein $(H)$ & 72.84 & 136.23 & 138.55 & 31.12 & 51.52 & 19.17 & 111.27 \\
\hline 7 low protein $(\mathrm{L})$ & 75.31 & 139.33 & 139.7 & 31.64 & 52.3 & 18.82 & 114.10 \\
\hline
\end{tabular}

(Bold: differences between divergent bulks statistically significant) 
Table 26: Mean values of individual bulks in cross 2 at high $\mathrm{N}$ supply

\begin{tabular}{|c|c|c|c|c|c|c|c|}
\hline Genotypes & $\begin{array}{l}\text { DWSEF } \\
d t / h a \\
(2 \text { Loc.) }\end{array}$ & $\begin{array}{l}\text { Nuptake }_{E F} \\
\mathrm{~kg} \mathrm{~N} / \mathrm{ha} \\
\text { (2 Loc.) }\end{array}$ & $\begin{array}{l}\text { Pl height } \\
\mathrm{cm} \\
\text { (4 Loc.) }\end{array}$ & $\begin{array}{l}\text { Yield } \\
\text { dt/ha } \\
\text { (4 Loc.) }\end{array}$ & $\begin{array}{l}\text { Oil } \\
\% \\
(3 \text { Loc.) }\end{array}$ & $\begin{array}{l}\text { Protein } \\
\% \\
\text { (3 Loc.) }\end{array}$ & $\begin{array}{l}\text { SNU } \\
k g N / h a \\
(3 \text { Loc.) }\end{array}$ \\
\hline Branching type & 116.61 & 260.08 & 150.36 & 37.21 & 46.94 & L 21.97 & 152.12 \\
\hline Low branching type & 103.40 & 250.53 & 152.13 & 38.55 & 47.22 & H 22.09 & 160.09 \\
\hline Short & 136.75 & 315.82 & 146.12 & 42.16 & 48.77 & H 22.27 & 168.63 \\
\hline Tall & 130.21 & 272.75 & 149.43 & 38.35 & 48.77 & L 21.81 & 157.53 \\
\hline High oil & 92.59 & 233.05 & 152.42 & 38.56 & 50.90 & L 21.47 & 157.54 \\
\hline Low oil & 105.26 & 242.60 & 151.46 & 39.95 & 46.47 & Н 21.91 & 160.06 \\
\hline High protein & 117.63 & 287.41 & 150.15 & 39.47 & 49.09 & H 22.21 & 159.73 \\
\hline Low protein & 144.30 & 327.80 & 151.74 & 43.60 & 48.87 & L 21.61 & 180.70 \\
\hline High TSW & 122.58 & 295.73 & 153.07 & 36.51 & 48.78 & L 21.75 & 147.20 \\
\hline Low TSW & 114.71 & 270.77 & 146.94 & 38.28 & 49.13 & Н 21.93 & 151.30 \\
\hline Early flowering & 116.83 & 268.26 & 148.55 & 40.41 & 48.77 & Н 22.23 & 171.24 \\
\hline Late flowering & 117.36 & 294.03 & 151.76 & 46.28 & 50.03 & L 21.52 & 167.65 \\
\hline High $\mathrm{N}$ d. leaves & 111.46 & 280.39 & 146.93 & 41.51 & 48.87 & Н 21.91 & 162.02 \\
\hline Low $\mathrm{N} \mathrm{d}$. leaves & 112.57 & 251.93 & 155.04 & 40.55 & 49.24 & L 21.88 & 162.68 \\
\hline LSD 0.05 & 33.9 & 84.7 & 7.2 & 7.1 & 0.8 & 0.7 & 23.5 \\
\hline 7 high protein $(\mathrm{H})$ & 115.15 & 273.68 & 148.9 & 40.05 & 48.33 & 22.08 & 161.88 \\
\hline 7 low protein $(\mathrm{L})$ & 119.46 & 276.48 & 151.97 & 40.15 & 49.08 & 21.72 & 160.77 \\
\hline
\end{tabular}

(Bold: differences between divergent bulks statistically significant)

Mean values of the genotypes in cross 2 at the average $N$ supply (Table 27) has shown that the significant differences between the low and high protein containing bulks has resulted in statistical differences in grain yield. here the low protein containing plants had high grain yields. It is also clear to be seen that the significant differences between high and low protein bulks has shown that low protein plants translocated more $\mathrm{N}$ to seed. 
Table 27: Mean values of bulks in cross 2. average of two $\mathrm{N}$ levels

\begin{tabular}{l|llllllc}
\hline Genotypes & DWSEF & Nuptake $_{E F}$ & Pl height & Yield & Oil & Protein & SNU \\
& $d t / h a$ & $k g N / h a$ & $c m$ & $d t / h a$ & $\%$ & $\%$ & kg N/ha \\
& $(2$ Loc.) & $(2$ Loc.) & $(5$ Loc.) & $(5$ Loc.) & (4 Loc.) & (4 Loc.) & (4 Loc.) \\
\hline Branching type & 95.80 & 196.26 & 143.82 & 35.07 & 48.54 & L 20.47 & 135.57 \\
Low branching type & 84.88 & 179.81 & 145.28 & 34.49 & 48.96 & H 20.56 & 133.99 \\
Short & 106.76 & 230.18 & 142.22 & 37.53 & 50.58 & H 20.67 & 142.15 \\
Tall & 104.44 & 210.36 & 143.82 & 34.72 & 50.32 & L 20.35 & 137.10 \\
High oil & 76.72 & 177.10 & 145.17 & 34.36 & $\mathbf{5 2 . 6 7}$ & L 20.11 & 132.61 \\
Low oil & 88.34 & 192.27 & 144.20 & 35.27 & $\mathbf{4 8 . 1 8}$ & H 20.47 & 135.46 \\
High protein & 98.04 & 222.82 & 144.74 & 35.57 & 50.77 & H 20.77 & $\mathbf{1 3 7 . 0 9}$ \\
Low protein & 113.61 & 238.90 & 145.91 & 38.60 & 50.37 & L 20.18 & $\mathbf{1 5 1 . 0 4}$ \\
High TSW & 101.49 & 220.93 & 148.40 & 33.82 & 50.17 & L 20.38 & 129.09 \\
Low TSW & 91.47 & 197.90 & 143.07 & 33.46 & 50.85 & H 20.44 & 126.96 \\
Early flowering & 89.79 & 192.31 & 142.15 & $\mathbf{3 5 . 0 2}$ & $\mathbf{5 0 . 2 6}$ & H 20.96 & 139.91 \\
Late flowering & 100.18 & 222.43 & 147.92 & $\mathbf{3 9 . 4 8}$ & $\mathbf{5 1 . 4 3}$ & L 20.14 & 142.73 \\
High N d. leaves & 92.61 & 208.83 & 142.15 & 36.50 & 50.38 & H 20.48 & 136.24 \\
Low N d. leaves & 95.50 & 200.32 & 148.09 & 36.45 & 50.83 & L 20.30 & 138.12 \\
LSD 0.05 & 19.6 & 47.0 & 5.9 & 4.4 & 0.7 & 0.6 & 13.7 \\
7 high protein (H) & 93.13 & 203.45 & 143.4 & 35.40 & 50.10 & 20.62 & 135.97 \\
7 low protein (L) & 98.25 & 209.47 & 146.16 & 36.07 & 50.62 & 20.28 & 138.04 \\
\hline (Botd: difencs & & & & & & &
\end{tabular}

(Bold: differences between divergent bulks statistically significant)

Mean value of the genotypes in cross 3 at low N supply are presented in (Table 28) and shows that plants with high $\mathrm{N}$ content in the plant had also high $\mathrm{N}$ content. short plants had high $\mathrm{N}$ uptake. but not significant differences in grain yields. At the high $\mathrm{N}$ level however. plants with low $\mathrm{N}$ content in the plant had high grain yields. tall plants had higher dry matter production at the end of flowering. early flowering had high protein and high seed $\mathrm{N}$ uptake and low protein containing had higher grain yields (Table 29). 
Table 28: Mean values of bulks in cross 3 without $\mathrm{N}$ supply

\begin{tabular}{|c|c|c|c|c|c|c|c|}
\hline Genotypes & $\begin{array}{l}\text { DWSEF } \\
d t / h a \\
(2 \text { Loc.) }\end{array}$ & $\begin{array}{l}\text { Nuptake }_{E F} \\
\mathrm{~kg} \mathrm{~N} / \mathrm{ha} \\
\text { (2 Loc.) }\end{array}$ & $\begin{array}{l}\text { Pl height } \\
\mathrm{cm} \\
\text { (5 Loc.) }\end{array}$ & $\begin{array}{l}\text { Yield } \\
d t / h a \\
(5 \text { Loc. })\end{array}$ & $\begin{array}{l}\text { Oil } \\
\% \\
(4 \text { Loc.) }\end{array}$ & $\begin{array}{l}\text { Protein } \\
\% \\
\text { (4 Loc.) }\end{array}$ & $\begin{array}{l}S N U \\
\quad \mathrm{~kg} \mathrm{~N} / \mathrm{ha} \\
\text { (4 Loc.) }\end{array}$ \\
\hline High oil & 74.7 & 140.7 & 143.9 & 32.9 & 51.8 & L 16.8 & 105.1 \\
\hline Low oil & 64.8 & 118.6 & 142.5 & 30.4 & 50.3 & H 18.0 & 102.7 \\
\hline High protein & 70.3 & 126.0 & 138.9 & 31.3 & 50.2 & H 18.3 & 108.5 \\
\hline Low protein & 73.4 & 140.0 & 142.0 & 34.4 & 50.8 & L 17.5 & 107.3 \\
\hline Early flowering & 75.7 & 138.9 & 141.3 & 32.4 & 50.4 & L 17.7 & 107.6 \\
\hline Late flowering & 80.1 & 150.8 & 147.7 & 33.5 & 50.2 & Н 18.3 & 112.3 \\
\hline Tall & 67.1 & 118.3 & 146.5 & 31.3 & 50.4 & Н 17.7 & 101.6 \\
\hline Short & 92.1 & 181.8 & 142.4 & 35.2 & 50.9 & L 17.3 & 109.9 \\
\hline High LAI & 70.1 & 122.7 & 141.2 & 33.0 & 50.9 & L 17.6 & 110.7 \\
\hline Low LAI & 72.7 & 120.6 & 144.0 & 32.9 & 50.6 & Н 17.9 & 114.2 \\
\hline High N d-leaves & 64.4 & 117.1 & 139.6 & 35.0 & 50.6 & L 17.1 & 113.9 \\
\hline Low $\mathrm{N}$ d-eaves & 79.2 & 156.2 & 142.8 & 32.6 & 50.7 & Н 17.6 & 108.6 \\
\hline High DwSEF & 77.6 & 141.3 & 145.7 & 33.2 & 50.9 & Н 17.8 & 108.5 \\
\hline Low DwSEF & 75.6 & 127.8 & 142.3 & 33.4 & 50.1 & L 18.2 & 114.8 \\
\hline High HI & 68.6 & 130.8 & 139.9 & 33.0 & 50.6 & L 17.4 & 106.9 \\
\hline Low HI & 86.7 & 163.1 & 139.9 & 31.0 & 51.2 & Н 17.6 & 104.0 \\
\hline High TSW & 63.3 & 156.6 & 145.9 & 34.4 & 50.4 & Н 17.7 & 111.1 \\
\hline Low TSW & 90.4 & 171.6 & 139.6 & 34.1 & 51.1 & L 16.9 & 109.2 \\
\hline High N straw & 71.6 & 138.4 & 139.2 & 34.0 & 52.1 & L 17.0 & 110.4 \\
\hline Low N straw & 71.0 & 130.4 & 144.0 & 31.6 & 51.0 & Н 17.5 & 103.4 \\
\hline LSD 0.05 & 27.5 & 63.3 & 7.1 & 4.3 & 1.0 & 0.8 & 13.8 \\
\hline 10 high protein $(H)$ & 73.28 & 138.09 & 143.79 & 64.42 & 50.59 & 17.84 & 107.49 \\
\hline 10 low protein (L) & 75.66 & 140.98 & 141.14 & 67.48 & 50.83 & 17.35 & 109.58 \\
\hline
\end{tabular}


Table 29: Mean values of bulks in cross 3 at high $\mathrm{N}$ supply

\begin{tabular}{|c|c|c|c|c|c|c|c|}
\hline Genotypes & $\begin{array}{l}\text { DWSEF } \\
d t / h a \\
(2 \text { Loc.) }\end{array}$ & $\begin{array}{l}\text { Nuptake }_{E F} \\
\mathrm{~kg} \mathrm{~N} / \mathrm{ha} \\
\text { (2 Loc.) }\end{array}$ & $\begin{array}{l}\text { Pl height } \\
\mathrm{cm} \\
\text { (5 Loc.) }\end{array}$ & $\begin{array}{l}\text { Yield } \\
d t / h a \\
(5 \text { Loc.) }\end{array}$ & $\begin{array}{l}\text { Oil } \\
\% \\
(4 \text { Loc.) }\end{array}$ & $\begin{array}{l}\text { Protein } \\
\% \\
\text { (4 Loc.) }\end{array}$ & $\begin{array}{l}\text { SNU } \\
k g ~ N / h a \\
\text { (4 Loc.) }\end{array}$ \\
\hline High oil & 125.0 & 313.9 & 159.0 & 43.7 & 48.6 & L 19.6 & 151.5 \\
\hline Low oil & 122.6 & 283.6 & 161.1 & 41.5 & 46.7 & Н 21.2 & 154.4 \\
\hline High protein & 125.6 & 291.8 & 156.2 & 39.9 & 47.0 & Н 21.0 & 147.1 \\
\hline Low protein & 125.7 & 286.8 & 159.3 & 46.1 & 47.9 & L 20.1 & 160.3 \\
\hline Early flowering & 120.5 & 297.6 & 161.7 & 43.6 & 47.3 & Н 20.7 & 162.8 \\
\hline Late flowering & 121.9 & 285.8 & 162.0 & 42.5 & 48.1 & L 20.0 & 143.9 \\
\hline Tall & 138.5 & 312.7 & 164.7 & 41.8 & 47.7 & L 20.3 & 153.5 \\
\hline Short & 101.4 & 231.1 & 156.6 & 43.7 & 47.4 & Н 20.3 & 155.5 \\
\hline High LAI & 132.3 & 329.7 & 159.4 & 44.1 & 47.3 & Н 20.6 & 165.8 \\
\hline Low LAI & 138.6 & 290.0 & 154.5 & 43.5 & 47.6 & L 20.2 & 163.0 \\
\hline High $\mathrm{N}$ d. leaves & 136.0 & 315.4 & 160.2 & 44.9 & 47.5 & Н 20.3 & 164.7 \\
\hline Low $\mathrm{N}$ d. leaves & 128.9 & 301.9 & 161.5 & 43.1 & 47.6 & L 20.1 & 157.2 \\
\hline High DWSEF & 134.8 & 299.6 & 158.2 & 42.9 & 48.0 & L 20.3 & 156.8 \\
\hline Low DWSEF & 138.4 & 324.8 & 163.6 & 42.2 & 47.4 & Н 20.5 & 154.6 \\
\hline High HI & 124.7 & 287.6 & 157.5 & 40.5 & 47.5 & L 20.2 & 158.1 \\
\hline Low HI & 121.7 & 273.6 & 152.2 & 41.7 & 47.5 & Н 20.5 & 157.4 \\
\hline High TSW & 127.8 & 282.9 & 160.8 & 45.4 & 47.2 & Н 20.8 & 165.2 \\
\hline Low TSW & 131.7 & 316.4 & 155.7 & 44.8 & 47.8 & L 20.0 & 160.4 \\
\hline High N strew & 120.7 & 273.1 & 154.9 & 39.6 & 48.5 & L 19.9 & 145.0 \\
\hline Low N strew & 116.0 & 266.9 & 159.4 & 45.2 & 48.3 & Н 19.9 & 161.5 \\
\hline LSD 0.05 & 33.7 & 87.3 & 6.6 & 5.0 & 0.9 & 0.6 & 18.6 \\
\hline 10 high protein $(H)$ & 124.23 & 286.74 & 159.12 & 86.44 & 47.36 & 20.58 & 158.9 \\
\hline 10 low protein (L) & 129.05 & 293.78 & 158.73 & 85.70 & 47.93 & 20.07 & 154.97 \\
\hline
\end{tabular}

(Bold: differences between divergent bulks statistically significant)

At the average $\mathrm{N}$ supply for this cross. though there was no differences in grain yield. bulks with bold seeds had higher protein content. The differences between low protein and high protein containing bulks were statistically significant. here low protein containing plant had also high grain yields (Table 30). 
Table 30: Mean values of bulks in cross 3. average of $2 \mathrm{~N}$ levels

\begin{tabular}{|c|c|c|c|c|c|c|c|}
\hline Genotypes & $\begin{array}{l}\text { DWSEF } \\
d t / h a \\
(2 \text { Loc.) }\end{array}$ & $\begin{array}{l}\text { Nuptake }_{E F} \\
\mathrm{~kg} \mathrm{~N} / \mathrm{ha} \\
(2 \text { Loc.) }\end{array}$ & $\begin{array}{l}\text { Pl height } \\
\mathrm{cm} \\
(5 \text { Loc.) }\end{array}$ & $\begin{array}{l}\text { Yield } \\
\text { dt/ha } \\
\text { (5 Loc.) }\end{array}$ & $\begin{array}{l}\text { Oil } \\
\% \\
\text { (4 Loc.) }\end{array}$ & $\begin{array}{l}\text { Protein } \\
\% \\
\text { (4 Loc.) }\end{array}$ & $\begin{array}{l}\text { SNU } \\
\mathrm{kg} \mathrm{N} / \mathrm{ha} \\
\text { (4 Loc.) }\end{array}$ \\
\hline High oil & 99.8 & 227.3 & 151.4 & 38.3 & 50.2 & L 18.2 & 128.3 \\
\hline Low oil & 93.7 & 201.1 & 151.8 & 35.9 & 48.5 & H 19.6 & 128.6 \\
\hline High protein & 98.0 & 208.9 & 147.6 & 35.6 & 48.6 & Н 19.6 & 127.8 \\
\hline Low protein & 99.6 & 213.4 & 150.7 & 40.3 & 49.4 & L 18.8 & 133.8 \\
\hline Early flowering & 98.1 & 218.3 & 151.5 & 38.0 & 48.9 & L 19.2 & 135.2 \\
\hline Late flowering & 101.0 & 218.3 & 154.9 & 38.0 & 49.1 & Н 19.2 & 128.1 \\
\hline Tall & 102.8 & 215.5 & 155.6 & 36.5 & 49.1 & H 19.0 & 127.6 \\
\hline Short & 96.7 & 206.5 & 149.5 & 39.5 & 49.1 & L 18.8 & 132.7 \\
\hline High LAI & 101.2 & 226.2 & 150.3 & 38.6 & 49.1 & L 19.1 & 138.2 \\
\hline Low LAI & 105.7 & 205.3 & 149.3 & 38.2 & 49.1 & H 19.1 & 138.6 \\
\hline High $\mathrm{N}$ d. leaves & 100.2 & 216.2 & 149.9 & 40.0 & 49.1 & L 18.7 & 139.3 \\
\hline Low $\mathrm{N}$ d. leaves & 104.1 & 229.0 & 152.2 & 37.8 & 49.2 & Н 18.9 & 132.9 \\
\hline High DwSEF & 106.2 & 220.5 & 152.0 & 38.0 & 49.4 & L 19.0 & 132.7 \\
\hline Low DweEF & 107.0 & 226.3 & 152.9 & 37.8 & 48.8 & H 19.4 & 134.7 \\
\hline High HI & 96.6 & 209.2 & 148.7 & 36.8 & 49.0 & L 18.8 & 132.5 \\
\hline Low HI & 104.2 & 218.4 & 146.0 & 36.3 & 49.4 & H 19.0 & 130.7 \\
\hline High TSW & 95.5 & 219.7 & 153.3 & 39.9 & 48.8 & Н 19.3 & 138.1 \\
\hline Low TSW & 111.0 & 244.0 & 147.6 & 39.5 & 49.5 & L 18.4 & 134.8 \\
\hline High N strew & 96.1 & 205.7 & 147.0 & 36.8 & 50.3 & L 18.5 & 127.7 \\
\hline Low N strew & 93.5 & 198.6 & 151.7 & 38.4 & 49.7 & H 18.7 & 132.4 \\
\hline LSD 0.05 & 23.2 & 60.9 & 5.3 & 4.1 & 0.8 & 0.5 & 13.9 \\
\hline 10 high protein $(\mathrm{H})$ & 100.55 & 214.11 & 151.53 & 74.88 & 49.03 & 19.18 & 131.95 \\
\hline 10 low protein $(\mathrm{L})$ & 100.55 & 218.73 & 149.86 & 77.16 & 49.40 & 18.75 & 133.52 \\
\hline
\end{tabular}

(Bold: differences between divergent bulks statistically significant)

As a general note. genotypes with low protein content were high yielding in all the different crosses. 


\subsection{Discussion}

Our results have shown a significant genetic variation for grain yield and dry matter production at the end of flowering under conditions of sub-optimal $\mathrm{N}$ supply in cross 1 . The $\mathrm{N}$ efficient genotype was characterised by tall and thick stems. this trend was also observed in high $\mathrm{N}$ level as well as on the average (though some differences were not statistically significant).

The cross 2 has shown significant genotypic differences in the $\mathrm{N}$ seed yield on the average. showing that the $\mathrm{N}$ efficient genotypes have high $\mathrm{N}$ seed uptake as well as high $\mathrm{N}$ stover uptake (not statistically significant). And because $\mathrm{N}$ seed yield is part of the utilisation efficiency. which is the ability of the genotype to produce yield out of the total $\mathrm{N}$ uptake. these genotypes are likely to be having high $\mathrm{N}$ harvest index and consequently high $\mathrm{N}$ use efficiency.

The results in cross 3 cross have shown significant genotypic variation for $\mathrm{N}$ seed yield ( in $\mathrm{N} 0$ ). whereby $\mathrm{N}$ efficient genotypes tend to early flowering.

The above traits were measured in order to characterise an $\mathrm{N}$ efficient oilseed rape either through an improved $\mathrm{N}$ uptake or utilisation efficiency. We shall concentrate here on utilisation efficiency which could be improved through:

1. A better translocation of $\mathrm{N}$ from the leaves. stem and siliques into the seed i.e by increasing $\mathrm{N}$ HI through reduction of the $\mathrm{N}$ strew content.

2. An increased harvest index (HI).

3. Low $\mathrm{N}$ content in the dropped leaves.

4. Reduced protein content

Our results have clearly shown that selection for high seed protein content will be at the expense of grain yield. this agrees with former works which resulted in the constantly observed negative relationship between protein and grain yield (Dudley et al., 1977; Simmonds, 1995). 
Wheat breeders have reported little success in the attempt to identify selection criteria based on simple physiological attributes to combine high yield and high protein content (Monaghan et al., 2001). In cereals the low yielding ability of the high protein genotypes is usually explained by the high energy needed for protein production compared to starch production. However. in oilseed rape lower protein content is generally related to increased oil content. This was also observed in most of the divergent bulks (see Tables 24 and 27). The metabolic energy required is for oil production at least as high as for protein production. Therefore the clear relationship between high grain yield and low protein content was not expected in oilseed rape.

Our findings on the other had contradicted Grami and La Croix (1977) who working with spring rape seed reported a direct relationship between $\mathrm{N}$ uptake and seed $\mathrm{N}$ content, and therefore concluded that selection for high seed $\mathrm{N}$ content leads to improved $\mathrm{N}$ uptake and translocation efficiency.

We therefore conclude that despite the differences in traits related to $\mathrm{N}$ efficiency. the phenotype of $\mathrm{N}$ efficient oilseed rape remains the same i.e. thick stemmed. tall. late maturing and low in seed protein content. 


\section{Summary}

Oilseed rape is produced today under high $\mathrm{N}$ fertiliser application. However. the crop is known to be having a low $\mathrm{N}$ efficiency mainly due to low translocation into the seed during the reproductive growth phase. despite the high $\mathrm{N}$ uptake early in the season until flowering. This results in a low $\mathrm{N}$ harvest index leaving behind a high $\mathrm{N}$ content in the strew which following mineralisation finds its way to ground water and thus contribute to environmental hazards.

$\mathrm{N}$ efficiency can be splitted into two components. namely $\mathrm{N}$ uptake (the efficiency with which the soil $\mathrm{N}$ can be taken up by the plant) and $\mathrm{N}$ utilisation (the seed dry weight produced pro unit of absorbed $\mathrm{N}$ fertiliser). Genotypic variation in $\mathrm{N}$ efficiency could generally be attributed to high $\mathrm{N}$ uptake and/ or high utilisation. A better understanding of the physiological basis for genetic variation in $\mathrm{N}$ efficiency would be very helpful to develop selection strategies to improve $\mathrm{N}$ efficiency. Therefore a large number of traits were measured which are thought to be related to $\mathrm{N}$ efficiency and could eventually serve as traits of indirect selection in improving $\mathrm{N}$ efficiency in oilseed rape.

Three experiments were conducted with field trials at different locations over one to three years with two $\mathrm{N}$ levels (without fertiliser and with $240 \mathrm{~kg} \mathrm{~N} / \mathrm{ha}$ ). The material consisted of doubled haploid lines (DH lines) derived from the crosses between the varieties Apex $\mathrm{x}$ Mohican. Bristol x Lirajet and Express x Mansholt as well as divergent bulks which were produced by mixing lines from these $\mathrm{DH}$ lines.

In the first experiment $54 \mathrm{DH}$ lines from the cross Apex x Mohican (cross 1) were tested in three years at seven environments. The genotypes $\mathrm{x}$ nitrogen interaction $(\mathrm{G} \times \mathrm{N})$ was highly significant and the size of their variance components was about $40 \%$ of the genetic variance. which is nearly the same size as the genotype $\mathrm{x}$ environment $(\mathrm{G} \times \mathrm{E})$ interaction. The lines with highest yield at high $\mathrm{N}$ supply showed sometimes rather low yields at the reduced $\mathrm{N}$ supply. At low $\mathrm{N}$ supply $62 \%$ of the variation in $\mathrm{N}$ efficiency was contributed by differences 
in $\mathrm{N}$ uptake efficiency. whereas at high $\mathrm{N}$ supply only $36 \%$ was contributed by differences in $\mathrm{N}$ uptake and $\mathrm{N}$ utilisation was more important.

In the second experiment $99 \mathrm{DH}$ lines from the cross Mansholt x Express (cross 2) were tested in two years at four environments. There was significant $\mathrm{G} \times \mathrm{N}$ interaction for all the traits except days to begin of flowering. end of flowering. $\mathrm{N}$ in dropped leaves and seed $\mathrm{N}$ uptake. The correlation between the two $\mathrm{N}$ levels for yield was $\mathrm{R}^{2}=0.53$ but after excluding three very low yielding lines the correlation was only $\mathrm{R}^{2}=0.35$. Yield/flowering interval and yield/end of flowering were significantly correlated at the reduced $\mathrm{N}$ supply but not at the high N supply.

In the third experiment 44 divergent bulks of cross 1 . cross 2 and cross 3 (Bristol x Lirajet) were tested in one year in 5 locations. The divergent bulks were composed from about 10 lines each which differed extremely for performance in morphological or agronomic traits.

The bulks of cross 1 differed significantly for all the traits except $\mathrm{N}$ uptake at end of flowering and seed $\mathrm{N}$ uptake. the bulks of cross 2 differed significantly only for oil content. the bulks of cross 3 showed significant genetic variation for plant height. oil and protein content. There was a clear relationship between protein content and high yield throughout the three crosses. the low protein containing lines proved to be high yielding. In conclusion. a large variation in both $\mathrm{N}$ uptake and utilisation existed. However. $\mathrm{N}$ efficiency is a complex character and no trait could be identified for an easy indirect selection. The development of cultivars with improved $\mathrm{N}$ efficiency is possible. but will require large breeding efforts. 


\section{Zusammenfassung}

Raps wird heute üblicherweise mit hoher mineralischer N-Düngung angebaut. Allerdings ist die N-Effizienz relativ gering, vor allem da zwar im zeitigen Frühjahr eine hohe N-Aufnahme stattfindet. aber nur relativ wenig $\mathrm{N}$ in die Samen verlagert wird. Dies resultiert in einem niedrigen N-Ernteindex und hohen N-Mengen, die im Stroh zurückbleiben und nach Mineralisation auswaschungsgefährdet sind und zu erheblichen Umweltbelastungen führen können.

Die N-Effizienz kann in zwei Komponenten aufgeteilt werden, nämlich die Aufnahmeeffizienz, mit der der im Boden verfügbare Stickstoff von der Pflanze aufgenommen wird, und die Nutzungseffizienz, also der je Einheit aufgenommenem Stickstoff produzierte Samenertrag. Genetische Variation in der N Effizienz kann grundsätzlich auf Unterschieden in der Aufnahmeeffizienz und/oder auf Unterschieden in der Nutzungseffizienz beruhen. Ein besseres Verständnis der Ursachen für genetische Unterschiede in der N-Effizienz würde die Entwicklung gezielter Selektionsverfahren wesentlich erleichtern.

Daher wurden in dieser Arbeit eine große Zahl von morphologischen und agronomischen Eigenschaften untersucht. die möglicherweise mit der N-Effizienz in Beziehung stehen und daher als indirekte Selektionsmerkmale dienen könnten. Es wurden drei unterschiedliche Experimente durchgeführt, die jeweils an mehreren Orten in ein bis drei Jahren in zwei NStufen (ohne Düngung und mit $240 \mathrm{~kg} \mathrm{~N} / \mathrm{ha}$ ) angebaut waren. Das Material bestand aus verdoppelten haploiden (DH) Linien aus drei Kreuzungspopulationen: Apex x Mohican, Bristol x Lirajet und Express x Mansholt. Außerdem wurden divergente Ramsche untersucht, die durch gezielte Mischung von DH-Linien aus diesen Populationen hergestellt wurden.

Im ersten Experiment wurden 54 DH-Linien aus der Kreuzung Apex x Mohican (Kreuzung 1) in drei Jahren an insgesamt sieben Umwelten angebaut. Die Genotyp-Stickstoff ( $\mathrm{G} \times \mathrm{N})$ Interaktion war hochsignifikant und die Größe der Varianzkomponente betrug etwa $40 \%$ der 
genetischen Varianz und war damit fast genauso groß wie die Interaktion zwischen Genotypen und Umwelten (G x E). Die Linien mit den höchsten Erträgen unter optimaler NVersorgung zeigten sehr unterschiedliche und teilweise eher niedrige Erträge in der Variante ohne N-Düngung. Bei niedriger N-Versorgung beruhte etwa $62 \%$ der genetischen Variation in der N-Effizienz auf Unterschieden in der Aufnahmeeffizienz, während bei hoher NDüngung nur $36 \%$ der genetischen Varianz durch Unterschiede in der N-Aufnahme erklärt werden konnte, und die Nutzungseffizienz eine größere Bedeutung hatte.

Im zweiten Experiment wurden 99 DH-Linien aus der Kreuzung Mansholt x Express (Kreuzung 2) in zwei Jahren an insgesamt vier Umwelten angebaut. Es traten für alle Merkmale signifikante Interaktionen zwischen Genotypen und N-Stufen auf, außer für Beginn und Ende der Blüte, N-Gehalt in den abgeworfenen Blättern und N-Ertrag der Samen. Die Erträge auf den beiden N-Stufen waren hoch korreliert $\left(\mathrm{R}^{2}=0.53\right)$, aber nach Ausschluss von drei sehr schwachwüchsigen Linien, die auf beiden N-Stufen sehr niedrige Erträge erbrachten, war diese Korrelation deutlich reduziert $\left(\mathrm{R}^{2}=0.35\right)$.

Im dritten Experiment wurden 44 divergente Ramsche aus Linien der drei Kreuzungen (Kreuzung 3: Bristol x Lirajet) in einem Jahr an 5 Umwelten angebaut. Diese divergenten Ramsche wurden so zusammengestellt, dass je etwa 10 Linien mit extrem unterschiedlicher Merkmalsausprägung gemischt wurden und als ein Prüfglied in den Feldversuchen getestet wurden. Die Ramsche der Kreuzung 1 zeigten signifikante Variation für alle Merkmale außer N-Aufnahme bis Blühende und Samen-Stickstoffertrag. Die Ramsche der Kreuzung 2 unterschieden sich dagegen signifikant nur im Ölgehalt und die Ramsche der Kreuzung 3 nur in der Wuchshöhe und dem Öl- und Proteingehalt. Die wichtigste, in allen drei Kreuzungen bestätigte Beobachtung war, dass in aller Regel ein hoher Kornertrag mit einem niedrigen Proteingehalt assoziiert ist.

Zusammenfassend kann festgestellt werden, dass eine große Variation in der N-Effizienz beim Raps nachgewiesen werden konnte. Allerdings wurde auch deutlich, dass die N- 
Effizienz ein sehr komplexes Zuchtziel ist, für das keine einfach zu selektierenden Hilfsmerkmale gefunden werden konnten. Somit ist die Verbesserung der N-Effizienz beim Raps zwar ein Zuchtziel mit großem Stellenwert, dass aber nur durch sehr hohe züchterische Anstrengung zu lösen sein wird. 


\section{References}

Aniol, H.. 1993: Ertrag. Ertragstruktur und Stickstoffaufnahme von Winterraps (Brassica napus L.) in Abhängigkeit von N-Menge. N-Verteilung und Genotyp. Diss., Kiel.

Aufhammer, W., Kübler. E., and Bury, M. 1994: Nitrogen uptake and nitrogen residuals of winter oilseed rape and fallout rape. J. Agronomy Crop Sci. 172: 255-264.

Becker. H.C., 1993: Pflanzenzüchtung. Ulmer Verlag, Stuttgart.

Becker, H.C. and Kazman, M.E. 2000: Genetische Variation für die Stickstoff-Effizienz bei Triticale. Vortr. Pflanzenzüchtung. 49, 111-117

Becker, H.C., Löptien, H. and Röbbelen, G. 1999: Breeding: An overview. In: GómezCampo. C., Biology of Brassica Coenospecies, Elsevier.

Behrens, T., 2001: Stickstoffeffizienz von Winterraps (Brassica napus L.) in Abhängigkeit von der Sorte sowie einer in Menge, Zeit und Form variierten Stickstoffdüngung. Diss., Universität Hannover.

Buzza, G.C., 1995: Plant breeding. In: Brassica Oilseeds Production and Utilization. CAB International, Wallingford, UK.

Dreccer, M.F., Schapendonk, A.H.C.M., Slafer, G.A. and Rabbinge, R., 2000: Comparative response of wheat and oilseed rape to nitrogen supply: Absorption and utilisation efficiency of radiation and nitrogen during the reproductive stages determining yield. Plant and Soil 220: 189-205.

Dudley, J.W., Lambert. R.J. and DE LA Roche, I.A. 1977: Genetic analysis of crosses among corn strains divergently selected for percent oil and protein. Crop Sci. 17, 111-117.

Dhugga, K.S. and Waines, J.G. 1989: Analysis of Nitrogen Accumulation and use in Bread and Durum Wheat. Crop Science 29, 1232-1239.

El Bassam, N. (Eds) 1990: Genetic Aspects of Plant Mineral Nutrition. Kluwer Academic Publishers, Dordrecht, Netherlands.

Gallais, A. 1983: use of indirect selection in plant breeding. In: Proceedings of the $10^{\text {th }}$ congress of the European Association for Research on Plant Breeding. EUCARPIA Wagenigen, the Netherlands 19-24 June 1983.

Graham, R.D. 1984: Breeding characteristics in cereals. In: Tinker, P.B. and Läuchli, A. (Eds.) Advances in Plant Nutrition. Vol. 1., Prager, New York: 57-90.

Grami, B. and La Croix, L.J., 1977: Cultivar variation in total nitrogen uptake in rape. Can. J. Plant Sci. 57, 619-624.

Gueye, T. 2002: Nitrogen efficiency of irrigated rice under West African conditions. Diss., Göttingen. 
Horst, W.J., Abou, M. and Wiesler, F. 1993: Genotypic differences in phosphorus efficiency of wheat. In: Barrow, N.J. (Ed.) Plant Nutrition-from genetic engeneering to field practice. Developments in Plant Science 45 Kluver Acad. Publ., pp. 367-370

Kessel, B. 2000: Genetische Variation und Vererbung der Stickstoff-Effizienz bei Winterraps (Brassica napus L.). Diss., Göttingen.

Kessel, B. and Becker, H.C. 1999a: Genetic variation of Nitrogen efficiency in field experiments with oilseed rape (Brassica napus L.). In: G.Gissel-Nielsen and A. Jensen (eds.). Plant Nutrition-Molecular Biology and Genetics. Kluwer Academic Publishers. pp. 391-395.

Kessel, B. and Becker, H.C. 1999b: Genetic variation of Nitrogen efficiency in field experiments with oilseed rape (Brassica napus L.). Proc. $10^{\text {th }}$ Intern. Rapeseed Congress. 26-29 September, Canberra, Australia

Kučera, V., Vyvadilová, M. and Klíma, M. 2002: Utilisation of double haploid in winter oilseed rape (Brassica napus L.) Breeding. Czech J. Genet. Plant Breed., 38, 2002 : 50-54.

Lickfett, T. 2000: Stickstoff Problematik in Rapsfruchtfolgen. In: Möllers, C. (Hrsg.) Stickstoff-Effizienz Landwirtschaftlicher Kulturpflanzen. Erich Schmidt Verlag.

Lickfett, T., 1993: Auswirkung verminderter poduktionsintensität in zwei Rapsfruchtfolgen auf Elemente des N-Haushalte im System Boden-Pflanze. Diss., Göttingen.

Ma, B.L. and Dwyer, L.M. 1998: Nitrogen uptake and use of two contrasting maize hybrids differing in leaf senescence. Plant and Soil 199, 283-291.

Maidl, F.X., Klemisch. M. and Wenzel, G. 2000: In: Möllers, C. (Hrsg.) Stickstoff-Effizienz Landwirtschaftlicher Kulturpflanzen. Erich Schmidt Verlag.

Monaghan, J.M., Snape, J.W.,Chojecki. A.J.S, and Kettlewell, P.S. the use of grain protein deviation for identifying wheat cultivars with high grain protein concentration and yield. Euphytica 122: 309-317, 2001.

Moll, R. H., Kamprath, E. J. and Jackson, W.A.1982: Analysis and interpretation of factors which contribute to efficiency of nitrogen utilisation. Agron. J. 74, 562-564.

Möllers, C. (Hrsg.) 2000: Stickstoff-Effizienz Landwirtschaftlicher Kulturpflanzen. Erich Schmidt Verlag.

Möllers, C., Kessel, B., Kahlmeyer, M., Ossenkop, A., und Becker, H. C. 2000: Untersuchungen zur genotypischen Variabilität der Stickstoff-effizienz bei Winterraps. In: Möllers, C. (Hrsg.) Stickstoff-Effizienz Landwirtschaftlicher Kulturpflanzen. Erich Schmidt Verlag.

Muruli, B.I. and Paulsen, G.M. 1981: Improvement of nitrogen use efficiency and its Relationship to other traits in maize. Maydica 26, 63-73. 
Ortiz-Monasterio, J.I.. Sayre, K.D., Rajaram. S. and McMahon. M. 1997: Genetic progress in wheat yield and nitrogen use efficiency under four nitrogen rates. Crop Sci. 37, 898904.

Presterl, E., Thiemt. E. and Geiger, H.H. 2000: Züchtung von Mais mit verbesserter Stickstoffeffizienz. In: Möllers, C. (Hrsg.) Stickstoff-Effizienz Landwirtschaftlicher Kulturpflanzen. Erich Schmidt Verlag.

Rauna, W.R. and Johnson, V. 1999: Improving nitrogen use efficiency for cereal production. Agron. J. 91: 357-363.

Reinhardt, T.C. 1992: Entwicklung und Anwendung von Nah-Infrarot-spektroskopischen Methoden für die Bestimmung von Öl. protein. Glucosolinat. Feuchte und Fettsäure Gehalten in intakter Rapsaat. Diss., Göttingen.

Riemer, H.M., Stelling, D. and Link, W. 2000: Genotypische Unterschiede in der N-Effizienz bei Körnerleguminosen. In: Möllers. C. (Hrsg.) Stickstoff-Effizienz Landwirtschaftlicher Kulturpflanzen. Erich Schmidt Verlag.

Sattelmacher, B., Horst, W.J. and Becker. H.C.. 1994: Factors that contribute to genetic variation for nutrient efficiency of crop plants. Z. Pflanzenernährung Bodenkunde 157, 215-224.

Schjoerring, J.K., 1995: Dynamics of nitrogen utilisation in Brassica napus. In: Proceeding for workshop of Brassica napus., pp. L-10.1-L10.7. 20-23 March 1995, Elsinore.

Simmsonds, N.W., 1995: The relation between yield and protein in cereal grain. J. Sci. Food Agric. 67: 309-315.

Spanakakis, A. 2000: Züchtung von Winterweizen mit verbesserter N-Effizienz. In: Möllers. C. (Hrsg.) Stickstoff-Effizienz Landwirtschaftlicher Kulturpflanzen. Erich Schmidt Verlag.

Utz, H.F. 1997: Ein Computerprogramm zur statistischen Analyse von Pflanzenzüchterischen Experimenten. Version 2 N. Institut für Pflanzenzüchtung und Populationsgenetik. Universität hohenheim.

Van Sanford, D.A and MacKown. C.T. 1986: Variation in nitrogen use efficiency among soft red winter wheat genotypes. Theor Appl Genet 72: 158-163

Velasco. L. and Möllers. C. 2000: Use of Near-Infrared Reflectance Spectroscopy to assess the nitrogen concentration in different plant tissues of rapeseed. Communications in Soil Science and Plant Analysis 31, 2987-2995.

Vose, P.B. 1990: Screening techniques for plant nutrient efficiency: Philosophy and methods. In: El Bassam. N. (Eds.). 283-289. Genetic Aspects of Plant Mineral Nutrition. Kluwer Academic Publishers. Dordrecht. 
Wiesler. F.. Behrens. T. and Horst. W.J. 2001: Nitrogen efficiency of contrasting rape ideotypes. In: W.J. Horst et al. (Eds). Plant nutrition-Food security and sustainability of agro-ecosystems. 60-61, 2001. Kluwer Academic Publishers. Netherlands.

Yau. S.K. and Thurling. N. 1987a: Variation in nitrogen response among spring rape (Brassica napus) cultivars and its relationship to nitrogen uptake and utilisation. Field Crops Res. 16, 139-155.

Yau. S.K. and Thurling. N. 1987b: Genetic variation in nitrogen uptake and utilisation in spring rape (Brassica napus) and its exploitation through selection. Plant Breeding 98, 330-338. 


\section{Aknowledgements}

I owe Prof. Dr. Heiko C. Becker more than thanks, who has supported me all the way long both academically and privately since 1995 when we first met during my M.Sc study which he has supervised. I am also very grateful unto him for the chance given me to do my Ph.D. at the Institute of Agronomy and Plant Breeding, without which I wouldn't have attained. I definitely thank him for all the supervision and the support during the course of the study which was characterised by patience, kindness and wisdom while resolving all the academic and research issues. My relationship with him is more than just an academic guide, Heiko from my self and family we just want to say thank you.

I am also very grateful to Prof. Dr. R. Rauber, who has kindly accepted to co-supervise this thesis despite the short notice. I appreciate his input to improve the thesis.

I am very thankful to Dr. Christian Möllers academically for providing materials which were helpful for my project and privately for the long time friendship and unreserved support, thanks is also extended to his family.

My thanks goes also to Dr. Bettina Kessel for introducing me into the project and Dr. Andreas Girke, who was all ways ready to help in all matters.

I would also like to thank Herr, G. Miotke for carrying out the field experiments as well as his help on the field. I would likewise want to thank Nicole Ritgen for her patience with Ph.D. students as she leads the teams on the fields. I have learned a lot on the field, therefore I would like to extend my gratitude to the field workers. I also thank Frau, Britta Appelt who patiently endured with me throughout this work as a technical assistant of this project.

My thanks goes also to all the academic staff at the institute for their academic input, generousity and financial support during the seminars and picnics, such were nice times to be remembered for long. I also thank all the Ph.D. students for nice company and diverse support. 
I do thank so much for the field experiments as well as the nice co-operation and generous reception the following breeding companies: KWS (Kleinwanzlebener Saatzucht), NPZ (Nordeutsche Pflanzenzucht), DSV (Deutsche Saatveredelung), Semundo Saatzucht GmbH. and the co-operation of the institute of plant nutrition- university of Hannover.

Much thanks I owe the DFG (Deutsche Forschungsgemeinschaft) for the financial support of this project.

Finally, I would like to thank my dear wife Nyachangjwok and son David whose time I have robbed, yet endured with me throughout this project, Part of my family are all my brothers and sisters in Christ who have supported me in all ways, God bless you. 


\section{Curriculum vitae}

\section{Personal Data}

Name:

Nationality:

Date of birth:

Place of birth:

\section{Education}

$1970-1976$

$1976-1979$

$1979-1982$

$1982-1987$

$1990-1993$

$1994-1997$

$2000-2003$

Since 2000

$1989-1990$
John Awan Nyikako

Sudanese

01.01 .1964

Malakal, Southern Sudan
Malakal Primary school

Malakal intermediate school

Malakal secondary school

Studied at the faculty of Agriculture (university of Alexandria, Egypt) and graduated with a degree of Bachelor of Science in plant Sciences. Studied at the faculty of Agriculture (university of Kharkov, Eukraine) and graduated with a degree of Masters of Science in plant production. Studied at the faculty of Agriculture (Georg-August-Universität, Germany) and graduated with a degree of Masters of Agricultural Sciences in Tropical and Subtropical studies.

Studied at the Institute of Agronomy and Plant Breeding (GeorgAugust-Universität, Germany) and was awarded a Ph. D. in plant Breeding.

\section{Work Experience}

Agronomist at El Shiek Mustafa El Amin Agricultural Company Ltd. working as a research assistant at the Institute of Agronomy and Plant Breeding (Georg-August-University, Göttingen). 